\title{
Contraception in women with obesity with special reference to gastric bypass surgery
}

\section{Charlotte Ginstman}

\section{LINKÖPING UNIVERSITY}




\title{
Contraception in women with obesity with special reference to gastric bypass surgery
}

\author{
Charlotte Ginstman
}

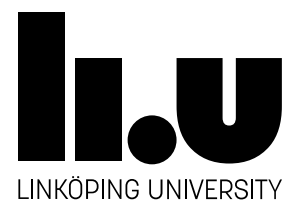

Department of Obstetrics and Gynecology Department of Clinical and Experimental Medicine

Linköping University, Linköping, Sweden

Linköping 2019 
Contraception in women with obesity with special reference to gastric bypass surgery (C) Charlotte Ginstman

Cover: published by permission of Shutterstock (www.shutterstock.com)

ISBN 978-91-7685-096-1

ISSN 0345-0082

Printed by LiU-tryck, Linköping, Sweden 2019 


\section{Abstract}

Background: The prevalence of obesity is increasing worldwide. The treatment of morbid obesity is dominated by bariatric surgery, for example Roux-en-Y gastric bypass (RYGB) surgery. If other contraceptive options are available, women with obesity should not be prescribed combined hormonal contraceptives due to the obesity-related increased risk of venous thromboembolism. Women are advised not to become pregnant during the first 12-18 months after RYGB surgery. There is a lack of knowledge of what type of contraceptive methods women with obesity are prescribed and whether they experience more or different side effects compared to normal-weight women. It is not known if the absorption and pharmacokinetic profile of progestins are affected by RYGB. The aim of this thesis was to investigate the pattern of contraceptive use in women with obesity, what type of contraceptive counselling was given to women in relation to RYGB, and whether the pharmacokinetics of two different progestins were affected by RYGB surgery.

Material and Methods: Paper I is a retrospective cohort study analysing the patterns of contraceptive prescription, adverse effects, duration of treatment, reasons for discontinuation and bleeding pattern in 371 women with obesity compared with 744 normal-weight women. Medical records were scrutinised from 1 Jan 2010 until 31 Dec 2014. Paper II is based on a questionnaire sent to 987 women who had undergone RYGB during 2010. The questionnaire concerned preoperative and present contraceptive use, contraceptive counselling in relation to surgery and what type of recommendations they had received regarding pregnancy after RYGB. Papers III and IV are experimental studies investigating the pharmacokinetics of desogestrel (etonogestrel) and levonorgestrel in relation to RYGB.

Results and conclusions: The most commonly prescribed contraceptive method for women with obesity was the progestin-only pill but many women with obesity were prescribed combined hormonal contraceptives despite the current recommendations of cautious prescription of oestrogen-containing methods. There were no differences in adherence to contraceptive method between women with obesity and normal-weight women. Despite the uncertainties regarding absorption, almost $10 \%$ of women continued using oral contraceptives after RYGB. Nearly $40 \%$ were not aware of the recommendation to avoid pregnancy in the first year after RYGB and almost one third did not use any contraception during this period. This could be due to a lack of information or that the women did not retain the given information to avoid pregnancy.

We found no clinically significant differences in the steady state pharmacokinetics of desogestrel before compared with after RYGB, or in single 
dose pharmacokinetics of levonorgestrel in women with $\mathrm{BMI}<30$ having undergone RYGB compared with BMI-matched non-operated women. This suggests that oral contraceptives containing desogestrel and levonorgestrel might be used after RYGB surgery. 


\section{List of scientific papers}

I. Patterns of prescription and discontinuation of contraceptives for Swedish women with obesity and normal weight-women Micaela Sundell*, Charlotte Ginstman*, Agnes Månsson, Ingrid Forslund, Jan Brynhildsen. Eur J Contracept Reprod Health. Accepted for publication * Equal contribution

II. Contraceptive use before and after gastric bypass: a questionnaire study

Charlotte Ginstman, Jessica Frisk, Johan Ottoson, Jan Brynhildsen Obes Surg. 2015 Nov;25(11):2066-70.

III. Plasma concentrations of etonogestrel in obese women using oral desogestrel before and after Roux-en-Y gastric bypass surgery (RYGB): a pharmacokinetic study

Charlotte Ginstman, Jessica Frisk, Björn Carlsson, Andreas Ärlemalm, Staffan Hägg, Jan Brynhildsen. BJOG. 2019 Mar;126(4):486-492.

IV. Pharmacokinetics of oral levonorgestrel in women after Roux-en$Y$ gastric bypass surgery and in BMI matched controls Charlotte Ginstman, Helena Kopp Kallner, Johanna Fagerberg-Silwer, Björn Carlsson, Andreas Ärlemalm, Ylva Böttiger, Jan Brynhildsen. Manuscript 



\section{Abbreviations}

$\begin{array}{ll}\text { AUC }_{(0-24 h)} & \text { Area under the serum concentration time curves from 0-24 h } \\ \text { AUC }_{0 \rightarrow \infty} & \text { Area under the serum concentration time curves from } \\ & \text { 0-infinity } \\ \text { BMI } & \text { Body Mass Index } \\ \text { C }_{(24 h)} & \text { Serum concentration at } 24 \mathrm{~h} \\ \text { CHC } & \text { Combined hormonal contraception } \\ \text { Cl } & \text { Apparent oral clearance } \\ \text { C }_{\max } & \text { Peak serum concentrations } \\ \text { COC } & \text { Combined oral contraception } \\ \text { DSG } & \text { Desogestrel } \\ \text { EE } & \text { Ethinyl estradiol } \\ \text { ENG } & \text { Etonogestrel } \\ \text { HRT } & \text { Hormone replacement therapy } \\ \text { IUD } & \text { Intrauterine device } \\ \text { LNG } & \text { Levonorgestrel } \\ \text { LNG-IUD } & \text { Levonorgestrel intrauterine device } \\ \text { LNG-IUS } & \text { Levonorgestrel intrauterine system } \\ \text { m/z } & \text { mass-to-charge ratio } \\ \text { NET } & \text { Noretisterone } \\ \text { OR } & \text { Odds ratio } \\ \text { POP } & \text { Progestin-only pill } \\ \text { RYGB } & \text { Roux-en-Y gastric bypass } \\ \text { SHBG } & \text { Sex Hormone-Binding Globulin } \\ \text { SOReg } & \text { Scandinavian Obesity Surgery Registry } \\ t_{1 / 2} & \text { Terminal half-life } \\ T_{(\max )} & \text { Time to peak serum concentrations } \\ \text { UPLC/MS-MS } & \text { Ultra-performance liquid chromatography/tandem mass } \\ & \text { spectrometry } \\ \text { VTE } & \text { Venous thromboembolism } \\ & \end{array}$





\section{Content}

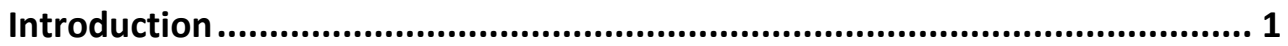

Obesity

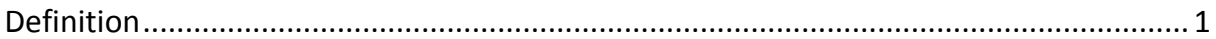

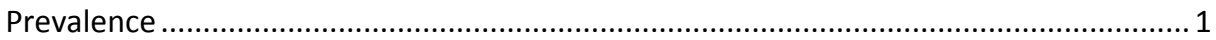

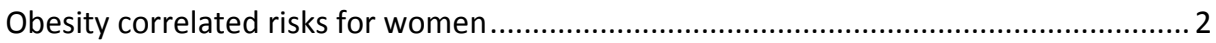

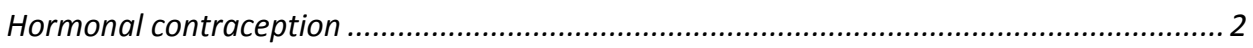

Combined oral contraceptives ........................................................................... 4

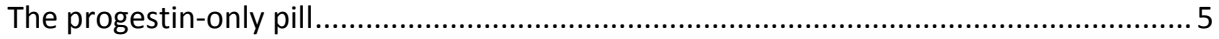

Blood transport of endogenous and exogenous hormones ........................................... 6

Pharmacokinetics of levonorgestrel and desogestrel................................................... 6

Obesity and contraception ........................................................................................ 7

Contraceptive efficacy in women with obesity compared with normal-weight women ..7

Thromboembolic disease, obesity and hormonal contraceptives.................................... 8

Contraceptive recommendations to women with obesity ……………………………. 9

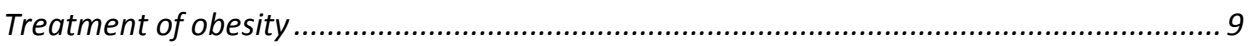

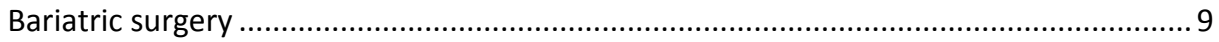

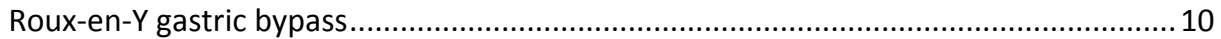

Roux-en-Y gastric bypass and women of fertile age ................................................... 12

Roux-en-Y gastric bypass and the pharmacokinetics of drugs .......................................12

Roux-en-Y gastric bypass and specific pharmacokinetic studies ...................................... 13

Specific background to the present studies..................................................................... 13

Contraceptive counselling to women with obesity and in relation to bariatric surgery (Paper I-II) ........................................................................................................ 13

Bariatric surgery and oral contraceptives (Paper III-IV) ................................................ 14

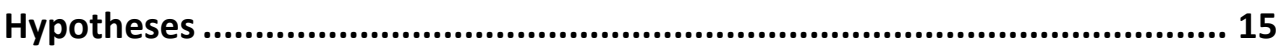

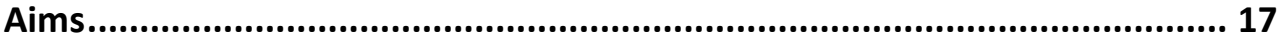

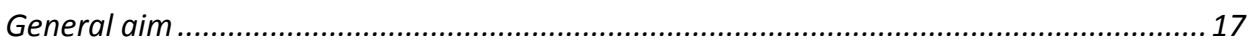

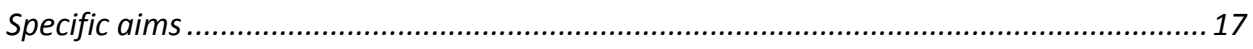

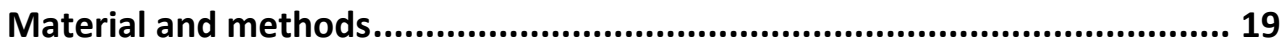

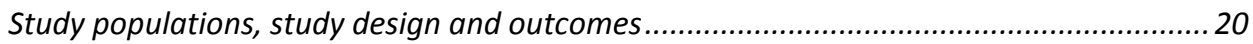

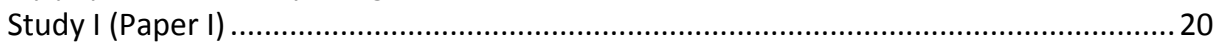

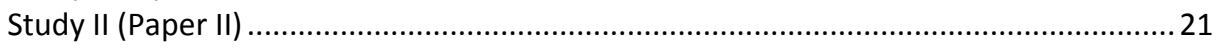

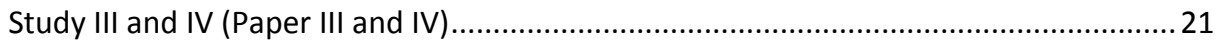

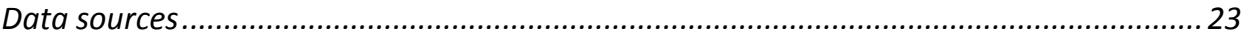

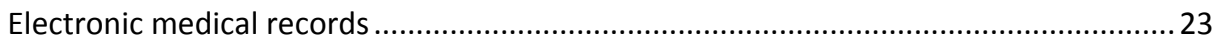

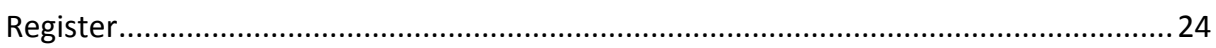

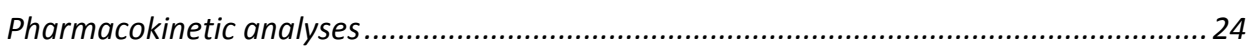




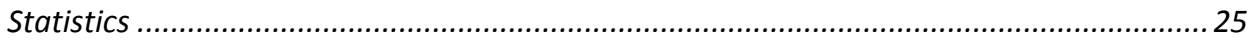

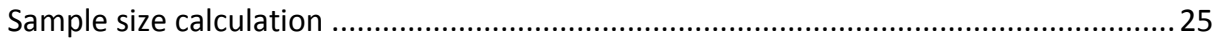

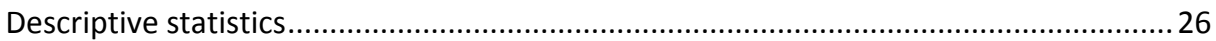

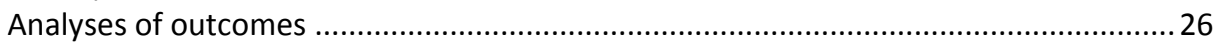

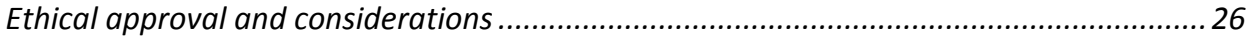

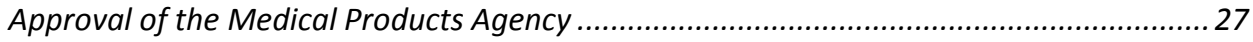

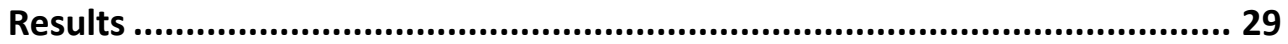

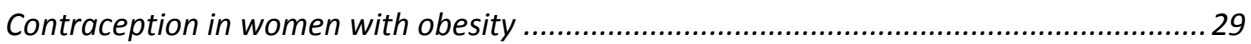

Prescription, side effects and discontinuation of contraceptives (paper I) ......................29

Contraceptive use in women in relation to RYGB (paper II) ........................................... 31

Comparison of contraceptive use in women with BMI>35 (papers I and II) ................... 33

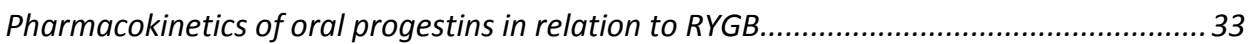

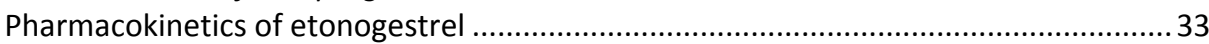

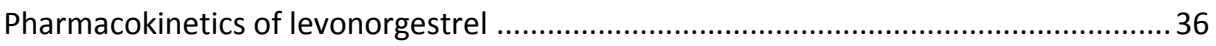

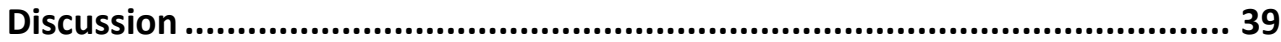

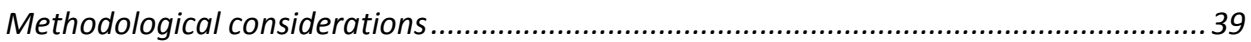

Retrospective cohort study versus cross-sectional questionnaire-based study .............. 39

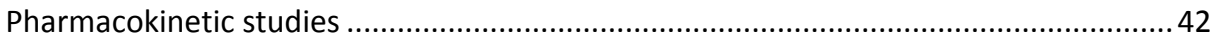

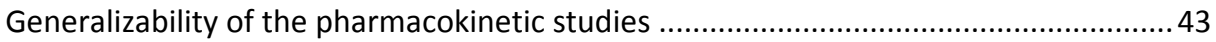

Methodological difficulties along the path as a PhD student ............................................4 44

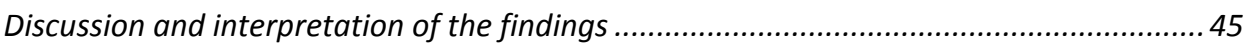

Contraceptive prescription, use, reported side effects and discontinuation (paper I-II) 45

Contraceptive counselling in relation to RYGB (paper II) ............................................ 47

Pharmacokinetics of ENG and LNG after RYGB (papers III and IV) .............................. 47

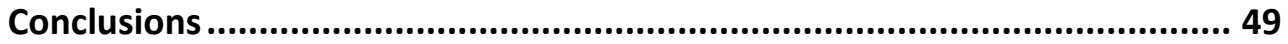

Future perspectives................................................................................. 51

Populärvetenskaplig sammanfattning ....................................................53

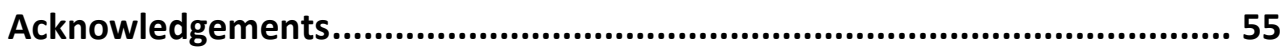

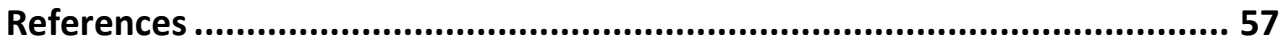

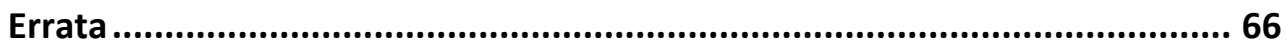

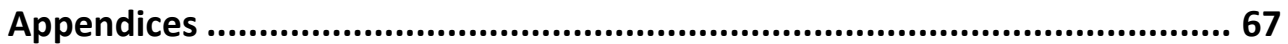

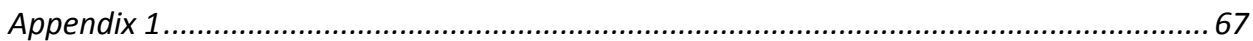

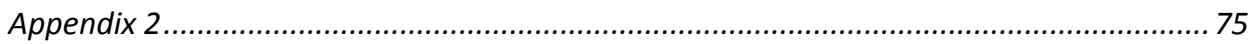




\title{
Introduction
}

\author{
Obesity
}

Definition

Obesity is defined as abnormal or excessive fat accumulation that may present a risk to health (1). Calculation of BMI is the most common method to classify overweight and obesity in adults (1). BMI is defined as an individual's weight in kilograms divided by the square of their height in metres $\left(\mathrm{kg} / \mathrm{m}^{2}\right)$.

\begin{tabular}{|l|l|}
\hline BMI $\left(\mathbf{k g} / \mathbf{m}^{\mathbf{2}}\right)$ & Classification \\
\hline$<18.5$ & Underweight \\
$18.5-24.9$ & Normal-weight \\
$25.0-29.9$ & Overweight \\
$30.0-34.9$ & Obesity class I \\
$35-39.9$ & Obesity class II \\
$\geq 40$ & Obesity class III (morbid obesity) \\
\hline
\end{tabular}

Table 1. WHO classification of obesity in adults (1).

Studies imply that specific BMI cut points may not reflect the same level of total fat mass, or abdominal obesity, between individuals of different sex and race (2). Also, it may not correspond to the same degree of fatness in different individuals. However, BMI is easy to measure and is used frequently in clinical studies as a population level measure of overweight and obesity. For children and adolescents, age needs to be considered when defining overweight and obesity and there are special charts and tables to define BMI for children (1).

\section{Prevalence}

The prevalence of obesity is increasing all over the world (3). More than 650 million adults were obese in 2016 , corresponding to $13 \%$ of the adult population (4). In the U.S, the prevalence of obesity among adults was estimated to be $39.8 \%$ in 2015-2016 (5). Among Swedish adults the prevalence of BMI $>30$ is considerably lower but increased from 11 to $16 \%$ from 2006 to 2018 (6). In 2018, seven percent of Swedish women aged 16-29 and 14\% aged 30-44 were obese (6). 


\section{Obesity correlated risks for women}

Obesity increases mortality and is correlated with increased risk of chronic disease such as depression, type 2 diabetes, cardiovascular disease, venous thromboembolism, obstructive sleep apnoea, certain cancers, and an overall decline in quality of life (7-11). Obesity is also correlated to insulin resistance, and together they constitute the major risk factors for non-alcoholic fatty liver disease, which is considered the most common cause of chronic liver disease and liver failure in Western countries (12). Obesity in women of reproductive ages also increases the risk of impaired reproduction i.e. anovulation, irregular menses, and increased risk of miscarriage $(13,14)$. Once pregnant, the obese woman faces an increased risk of obstetric maternal and perinatal complications, i.e. preeclampsia, gestational hypertension, gestational diabetes, postpartum haemorrhage, preterm delivery, and birth defects compared with normal-weight women (14-16).

\section{Hormonal contraception}

Progestogens, also sometimes written progestagens or gestagens, are a class of steroid hormones that bind to and activate the progesterone receptor (17). Progesterone is the major and most important progestogen in the body. Progestins are synthetic progestogens and have similar effects to those of progesterone (18). The progestogens used in hormonal contraception are all progestins.

Oestrogens used in hormonal contraception are the synthetic oestrogen ethinylestradiol and estradiol valerate. The latter is rapidly converted to estradiol, which is the main biologically active "natural" oestrogen. Also, estradiol is used in hormonal contraception.

The term 'combined hormonal contraception' (CHC) refers to contraceptives including both an oestrogen and a progestin. In Sweden there are three different routes by which these contraceptives can be administered; orally by the combined oral contraceptive pill (COC), vaginally by use of the vaginal ring, or transdermally with use of the contraceptive patch.

Progestin-only methods can be used as a progestin-only pill (POP), an implant, with a depot injection, or via an intrauterine system (LNG-IUS) (Table 2). 


\begin{tabular}{|c|c|c|c|c|c|c|}
\hline Compound & $\mathrm{CHC}^{*}$ & POP $^{* *}$ & Implant & IUS $^{\#}$ & Injectable & $\mathbf{E C P}^{\circ}$ \\
\hline \multicolumn{7}{|l|}{ Oestrogens } \\
\hline Ethinylestradiol & $\mathrm{X}$ & & & & & \\
\hline Estradiol & $\mathrm{X}$ & & & & & \\
\hline \multicolumn{7}{|l|}{ Progestins } \\
\hline Levonorgestrel & $\mathrm{X}$ & & & $\mathrm{X}$ & & $\mathrm{X}$ \\
\hline Norethisterone & & $\mathrm{X}$ & & & & \\
\hline Lynestrenol & & $\mathrm{X}$ & & & & \\
\hline Desogestrel & $\mathrm{X}$ & $\mathrm{X}$ & & & & \\
\hline Etonogestrel & $\mathrm{X}$ & & $\mathrm{X}$ & & & \\
\hline Drospirenone & $\mathrm{X}$ & & & & & \\
\hline Nomegestrol acetate & $\mathrm{X}$ & & & & & \\
\hline Dienogest & $\mathrm{X}$ & & & & & \\
\hline Norgestimate & $\mathrm{X}$ & & & & & \\
\hline Norelgestromine & $\mathrm{X}$ & & & & & \\
\hline Medroxyprogesteroneacetate & & & & & $\mathrm{X}$ & \\
\hline
\end{tabular}

Table 2. Oestrogens and progestins in hormonal contraceptives available in Sweden 2019. "CHCcombined hormonal contraception, ${ }^{* *} \mathrm{POP}$ - progestin-only pill, ${ }^{\#}$ IUS- intrauterine system, ${ }^{\circ} \mathrm{ECP}-$ emergency contraceptive pill

Since the first COC was introduced there have been stepwise changes of the pill. Different contraceptive alternatives have developed with a gradual decrease in oestrogen content, the introduction of new progestins and subsequently new oestrogens. Also, the elaboration of various oestrogen-progestin administration schemes and the development of alternative routes of administration have occurred over time (19). Because the natural estradiol is poorly absorbed when taken orally, and also quickly deactivated in the liver, the first COC contained synthetic oestrogens. The first COC contained $150 \mu \mathrm{g}$ of mestranol and $10 \mathrm{mg}$ of norethynodrel. The oestrogen compound of the pill, mestranol, was soon replaced by ethinylestradiol (EE) which is the active metabolite of mestranol. The first alarm about the increased thromboembolic risks related to oestrogen doses (20) resulted in gradual reduction in the doses of EE from $50 \mu \mathrm{g}$ to as low as $15 \mu \mathrm{g}(21)$. Theoretically, COCs that contain compounds that more closely resemble endogenous hormones may have fewer side effects. Therefore, estradiol valerate was developed as a potent alternative to EE. To reduce the androgenic side effects of the progestins, different progestin compounds were developed. Firstly, norethynodrel was exchanged for norethisterone (NET) and also lynestrenol, a prodrug of NET. A second-generation of COCs contained levonorgestrel (LNG). Oral contraceptives containing LNG and EE 
in different doses have been the pills most frequently used since the end of the 1960s. The development of the second-generation progestin LNG also made a reduction of progestin dosage possible.

Early studies of COCs showed a risk of COC related to the occurrence of venous thromboembolism (VTE), ischaemic stroke, and acute myocardial infarction (22). The main risk was initially thought to be related to the oestrogen component and therefore various progestins were developed so that the oestrogen doses in COCs could be reduced (23).

Apart from a wish to minimise these major side effects of COCs, there was also an attempt to decrease the level of androgen activity of the progestins, which led to the development of a third generation of COCs $(24,25)$. The aim was to reduce the minor side effects of progestins, such as acne, hirsutism, and weight gain. The third generation of COCs contains low doses of EE $(<35 \mu \mathrm{g})$ combined with desogestrel (DSG), gestodene or norgestimate.

A fourth generation of COCs has subsequently been developed containing the progestins drospirenone, dienogest or nomegestrol acetate. Drospirenone is a progestin that is analogue to spironolactone and is structurally very similar to progesterone. Both drospirenone and dienogest lack androgenic effects but show a partial anti-androgenic effect. They may have an effect on pre-existing androgen-related conditions such as acne and hirsutism (26). In the COCs available in Sweden, dienogest is combined with either EE or with estradiol valerate.

For first-time users, the most commonly prescribed contraceptives in Sweden in the period 2007-2009 were levonorgestrel containing COC (43.3\%) and the desogestrel-only pill (24.4\%) (27). More recent data are lacking.

The risk of becoming pregnant despite use of contraceptives is commonly presented as the Pearl Index, which is the number of women experiencing an unintended pregnancy per 100 women per year (Table 3).

\section{Combined oral contraceptives}

Even though the oestrogen component of the COC prevents the emergence of a dominant follicle through suppression of follicle-stimulating hormone secretion, it is the progestin component of COCs that prevents ovulation (25). The oestrogen component is added primarily to achieve regular bleedings and to balance the side effects of the progestins (25). 


\begin{tabular}{|c|c|c|}
\hline Method & $\begin{array}{l}\text { Pearl index with perfect } \\
\text { use }\end{array}$ & $\begin{array}{l}\text { Estimated pearl index for typical } \\
\text { use }\end{array}$ \\
\hline No method & 85 & 85 \\
\hline Male sterilisation & 0.10 & 0.15 \\
\hline Female sterilisation & 0.5 & 0.5 \\
\hline LNG-IUS*(Mirena) & 0.2 & 0.2 \\
\hline Cu-IUD** $\left(\geq 300 \mathrm{~mm}^{2}\right)$ & 0.6 & 0.8 \\
\hline $\mathrm{CHC}^{* * *}$ & 0.3 & 9 \\
\hline Progestin injectable & 0.2 & 6 \\
\hline Progestin implant & 0.05 & 0.05 \\
\hline POP $^{\#}$ - medium dose & 0.3 & 9 \\
\hline POP ${ }^{\#}$ - low dose & 1.1 & $>9$ \\
\hline Diaphragm & 6 & 12 \\
\hline Spermicides & 18 & 40 \\
\hline Male condom & 2 & 18 \\
\hline $\begin{array}{l}\text { Periodic abstinence -"natural } \\
\text { family planning" }\end{array}$ & $3-5$ & 24 \\
\hline
\end{tabular}

Table 3. Pearl Index (number of women experiencing an unintended pregnancy per 100 women per year) for different methods with perfect use. Estimated Pearl Index for different contraceptive methods with "typical use" (28). *LNG-IUS- levonorgestrel intrauterine system; **Cu-IUD - copper intrauterine device; $* * * \mathrm{CHC}$ - combined hormonal contraception regardless of administration route, \#POP - progestin-only pill

Combined hormonal contraception is the most commonly used contraceptive method in Sweden (29). Approximately $80 \%$ of Swedish women are believed to be ever users of COC (30). However, the pattern of contraceptive use has changed and progestin-only methods as well as intrauterine contraception have become more common during the last 15 years. The Swedish national guidelines on contraception do not primarily recommend usage of COC for women with obesity (31) which can explain, at least partly, why the use of POP is far more common in Sweden than in other parts of the world $(27,32)$.

\section{The progestin-only pill}

Traditional POPs on the Swedish market are low dose preparations of NET or lynestrenol (31). These low dose POPs prevent pregnancy primarily through other mechanisms than inhibition of ovulation. Their main effect is to cause the cervical mucus to become highly viscous, cellular and also scanty, which hampers the penetration of the sperms into the uterus (33). The endometrium is also prevented from proliferation and becomes thinner and less vascularised making it less suitable for implantation (34). 
The desogestrel-only pill is a medium dose POP containing $75 \mu \mathrm{g}$ of DSG, and differs from other POPs in providing consistent inhibition of ovulation $(35,36)$. The desogestrel-only pill has been shown to inhibit ovulation even with a 12-h delay in tablet intake, which makes it comparable to COCs (37). The traditional POPs have a safety margin of a three- to six-hour delay in tablet intake, with the consequence that timing of tablet ingestion and compliance are crucial. Side effects related to DSG and LNG containing POPs are bleeding/spotting episodes where DSG containing POPs seems to give a more unpredictable bleeding pattern than LNG containing POPs (38). Other side effects of POPs include for example acne, headache, nausea, breast pain, mental side effects and vaginitis (38).

\section{Blood transport of endogenous and exogenous hormones}

A majority of the estradiol and testosterone, is bound to a protein carrier; sex hormone-binding globulin (SHGB), mainly produced in the liver. Another $30 \%$ of the hormones are loosely bound to albumin, leaving about $1 \%$ unbound and free.

It is the free, unbound portion of hormones that exert the biologic effect. The albumin-bound fraction of steroids may also be available for cellular action because this binding has low affinity. The concentration of albumin in plasma is substantially higher than the concentration of SHBG and hence the contribution of the albumin bound fraction of sexual hormones can be significant (25). Hyperthyroidism, pregnancy and oestrogen administration increase serum concentrations of SHGB whereas androgens and progestins together with corticoids, insulin, and growth hormone decrease the serum concentrations of SHBG (25).

A significant weight gain, insulin resistance, or hyperinsulinemia can decrease circulating levels of SHBG thus increasing the unbound levels of sex hormones (25). It has been shown that non-alcoholic fatty liver disease is correlated to low levels of SHBG $(39,40)$; thereby also increasing unbound sex hormones.

\section{Pharmacokinetics of levonorgestrel and desogestrel}

The most commonly used COCs in Sweden contain the progestin LNG. LNG is rapidly absorbed in the intestines and after a dose of $150 \mu \mathrm{g}$ it reaches a maximum serum concentration $\left(\mathrm{C}_{\max }\right)$ of $3-4 \mathrm{ng} / \mathrm{ml}$ after approximately one hour $\left(\mathrm{T}_{\max }\right)(41-43)$. Like other progestins, $\mathrm{LNG}$ is bound to serum albumin and SHBG. Only $1.3 \%$ of the total serum concentration of LNG has been reported to be unbound; approximately $64 \%$ is bound to SHGB and $35 \%$ is bound to albumin (41). A study of LNG implants found that women with steady state concentrations above $0.3 \mathrm{ng} / \mathrm{ml}$ were protected from pregnancy (44). 
Cytochrome P450 3A (CYP3A4) isoenzyme is the most important enzyme involved in the metabolism of LNG, which mainly takes place in the liver. LNG is excreted though the urine and faeces (41).

The desogestrel-only pill is the most commonly prescribed POP in Sweden (27). As with LNG it is rapidly absorbed in the intestines. Progestins have been assumed to be predominantly absorbed in the upper part of the gastrointestinal tract $(45,46)$, but absorption of DSG has also been shown to take place in the colon (47). Desogestrel is metabolised to its active metabolite etonogestrel (ENG) in the liver but also in the intestinal mucosa $(47,48)$. ENG is primarily metabolised through CYP3A and is thereafter conjugated. It is excreted through the urine and faeces. Up to $99 \%$ of ENG is bound to plasma proteins, primarily to albumin and to a lesser extent to SHBG.

After oral intake of $75 \mu \mathrm{g}$ of DSG the pharmacokinetics of ENG show a $\mathrm{C}_{\max }$ of $0.8 \mathrm{ng} / \mathrm{ml}$, serum concentration through levels $\left(\mathrm{C}_{24 \mathrm{~h}}\right)$ of approximately 0.3 $\mathrm{ng} / \mathrm{ml}$, area under the serum concentration time curve (AUC $(0-\infty)$ ) of approximately $6 \mathrm{ng} * \mathrm{~h} / \mathrm{ml}$ and a $\mathrm{T}_{\max }$ of $1.4 \mathrm{~h}(49,50)$. A previous study of ENG implants demonstrated inhibition of ovulation when remaining at a serum concentration level above $0.09 \mathrm{ng} / \mathrm{ml}$ (51). However, inter-individual differences might exist; ovulation was identified in one case of serum concentrations at 0.12 $\mathrm{ng} / \mathrm{ml}$ when studying ENG implants (52).

\section{Obesity and contraception}

\section{Contraceptive efficacy in women with obesity compared with normal-weight women}

Even though the fertility might be reduced by the obesity-related increased risk of anovulation, women with obesity have the same need for safe and effective contraception. Theoretically, obesity may have an impact on the effect of hormonal contraceptives as well as on other pharmacological treatments. Historically, contraceptive clinical trials have excluded women whose body weight is over $130 \%$ of the ideal level, with the consequence that there is a gap in the knowledge about contraceptive efficacy in this population (53). Despite indications of a variation in the pharmacokinetics of COC depending on BMI $(54,55)$, ovulation seems to be adequately suppressed in COC users with obesity (56-58). Several studies, including a Cochrane Review from 2016, have not found an association between increased BMI and decreased effectiveness of combined hormonal contraceptives $(53,56,59,60)$. However, even if differences in pharmacokinetic profiles do not seem to result in ovulation or unintended pregnancies $(57,61,62)$ many obese women using COC seem to have a considerable ovarian follicular activity, although they have shown no overt evidence of ovulation (58). 
There are limited data on POP efficacy in women who are overweight or women with obesity. One observational study from the UK found no association between body weight and contraceptive failure in traditional POP users (63); however, this study had several limitations, including lack of differentiation between overweight and obesity. No studies have compared the effectiveness of the DSG pill in women of differing weights or BMIs.

Despite the differences in the metabolism of contraceptive hormones in women with obesity, the effectiveness of the studied contraceptive methods does not seem to be compromised. However, it should be emphasised that the combined hormonal patch and LNG-containing emergency contraception may have a lower rate of effectiveness in obese women, although superior to barrier methods or no method at all (53).

\section{Thromboembolic disease, obesity and hormonal contraceptives}

Obesity is associated with a two- or three-fold increased risk of VTE (64-66). Use of oestrogen, one of the main components of COC, is also an independent risk factor for VTE (64) whereas use of progestins alone does not seem to have these prothrombotic effects. The risk of VTE when using CHC increases with increasing BMI and age $(65,67)$ (Figure 1).

Reducing the dose of EE from 30-40 $\mu \mathrm{g}$ to $20 \mu \mathrm{g}$ reduces the risk for VTE with an odds ratio (OR) of 0.6 (0.4-0.9) (68).

The progestin component of COCs seems to have the ability to balance and counteract the prothrombotic effect of the oestrogen. The degree to which these progestins balance the prothrombotic effects seems to vary between different progestins. A review showed that the use of drospirenone containing $\mathrm{CHC}$ was associated with a higher risk of VTE compared with LNG containing CHC (69). Another review compared different COCs containing EE and progestins such as gestodene, DSG, cyproterone acetate, and drospirenone with COCs containing $\mathrm{EE}$ and low dose LNG. The relative risk of VTE for COCs with these more modern progestins was similar and about $50-80 \%$ higher than for COCs with LNG (70). As a consequence, the Swedish guidelines recommend CHC containing LNG, norgestimate or NET as the first choice of COC (31).

A plausible mechanism to explain these thrombotic risk differences associated with the use of second- and third-generation oral contraceptives (OCs) has long been debated. The differential changes of the proteins involved in the protein $\mathrm{C}$ system may contribute to the thrombotic effects of oral contraceptives. Kemmeren and co-workers (71) (2004) found that third-generation oral contraceptives had a stronger effect on anticoagulant parameters than secondgeneration preparations. These effects were not found with the progestin components of these pills only. 
They concluded that due to their androgenic properties, progestins induce changes in the anticoagulant system that are opposite to those of oestrogen, and that, due to the higher androgenicity, are more pronounced with levonorgestrel than with desogestrel, or other third or fourth generation COCs. They proposed that combining oral contraceptives with desogestrel induced more profound changes of the anticoagulant system than taking levonorgestrel alone.

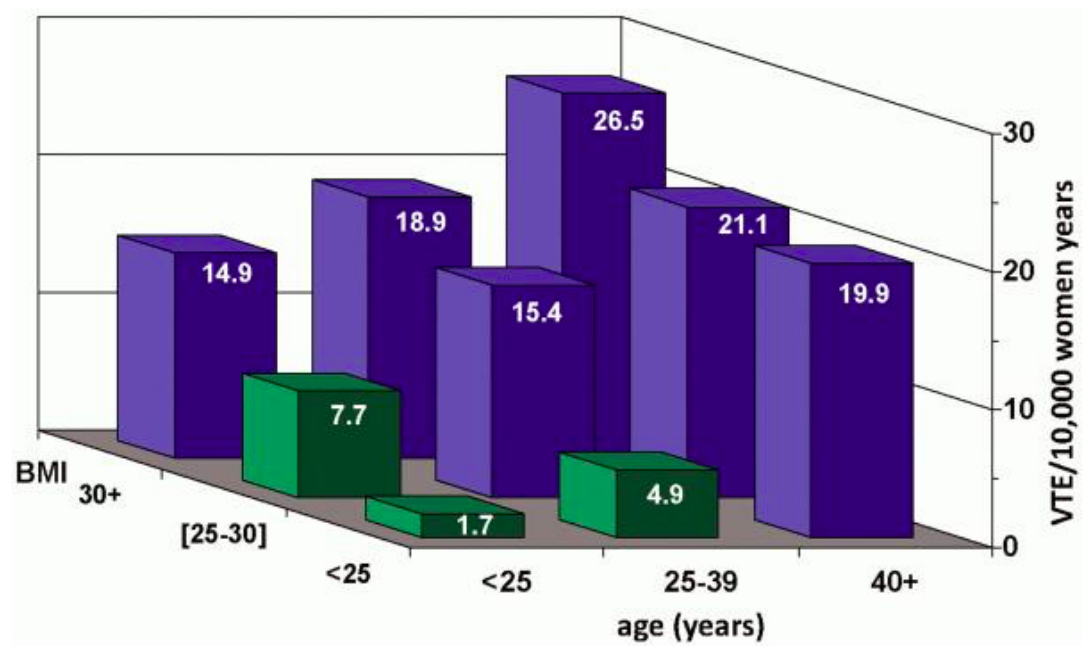

Figure 1. BMI and age as risk factors for venous thromboembolism with combined oral contraceptive use. Weight and age are independent risk factors with additive effects. Published by permission of the author (67).

\section{Contraceptive recommendations to women with obesity}

Due to the enhanced risk of venous thromboembolism in women with obesity using COCs the guidelines of the European Society of Contraception and Reproductive health (ESC) and the Swedish Medical Product Agency (MPA) do not primarily recommend $\mathrm{CHC}$ to women with $\mathrm{BMI}>30$ even if the women do not have any other risk factors for VTE $(31,72)$. Progestin-only contraceptives are instead recommended as the first contraceptive choice.

\section{Treatment of obesity}

\section{Bariatric surgery}

For more than a decade, treatment of obesity class II or more, i.e. BMI $>35$, has been dominated by bariatric surgery. Surgery results in greater improvement in weight loss outcomes and decreased weight associated comorbidities compared with non-surgical interventions, regardless of the type of procedure 
used (73). The Swedish Obese Subjects (SOS) study showed, in 20-year outcome data, that patients who received bariatric surgery achieved a significantly greater mean body weight reduction of approximately $18 \%$ compared with approximately $1 \%$ in patients who received standard medical treatment through their local health care centres (74).

If a concomitant disorder such as diabetes, cardiovascular disease, joint disease, severe sleep apnoea, or infertility is present, the indication for surgery is even stronger. Roux-en-Y gastric bypass is still the leading surgical technique in Sweden (75), but worldwide, sleeve gastrectomy is now dominating (76). Approximately 635000 primary bariatric procedures were performed worldwide in 2016 (76).

From 2002 the number of bariatric surgery procedures increased dramatically in Sweden from about 800 per year to 8500 per year in 2011 , followed by a decline to nearly 5400 procedures in 2017 . In $2010-2012$, RYGB constituted $95-97 \%$ of all bariatric surgery procedures in Sweden. Since then, there has been a switch towards sleeve gastrectomy. RYGB is still (2017) the most common procedure in Sweden (50.4\%), but sleeve gastrectomy has increased to $40.5 \%$ (75). Outcomes such as weight loss and improvements in comorbidities seem to be similar for RYGB and sleeve gastrectomy (73), but more studies are needed to confirm these results. There is an ongoing randomised clinical trial in Sweden, the Bypass Equipoise Sleeve Trial (BEST, NCT02767505) which aims to compare the two methods regarding weight loss, improvements in comorbidities and surgically-related complications in 2100 patients.

\section{Roux-en-Y gastric bypass}

RYGB involves both restrictive and malabsorptive components, which were long considered the weight-losing mechanisms alone. The restrictive part consists of the formation of a small proximal gastric pouch that holds $15-50 \mathrm{~mL}$, along the lesser curvature of the stomach. The jejunum is then incised 30 to 75 $\mathrm{cm}$ distal of the ligament of Trietz and a gastrojejuneal anastomosis is performed. The bypassed section of the ventricle, duodenum and upper part of the jejunum is then reconnected through a jejunojejuneal anastomosis to facilitate the passage of bile salts, stomach acid and pancreatic enzymes so they can mix with ingested food and drugs (77). This is the Roux-en-Y construction, which prevents approximately $150 \mathrm{~cm}$ of the small intestine from regular or any uptake (Figure 2). 


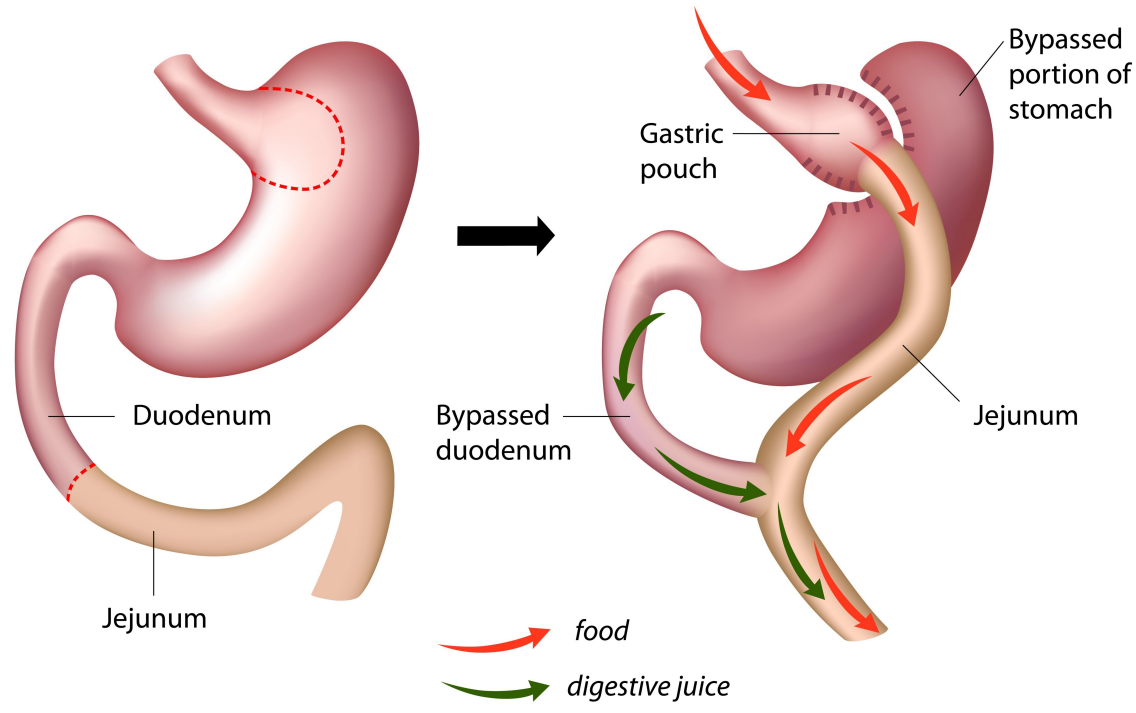

Figure 2. The Roux-en-Y Gastric Bypass. Published by permission of Shutterstock (www.shutterstock.com)

The mechanisms promoting weight loss following RYGB are still not fully understood. However, it is clear that the beneficial effects are not achieved through malabsorption and restriction alone, but rather hormonal changes. Altered eating behaviour, with reduced energy intake, is recognised as the main driver for weight loss (78). These changes of eating behaviour result from multiple mechanisms, where gut hormones seem to have a major role. The enteroendocrine $\mathrm{L}$ cells of the gastrointestinal tract secrete peptide YY3-36 (PYY) and glucagon-like peptide-1 (GLP-1), in response to ingestion of nutrients $(79,80)$. Both PYY and GLP-1 have an appetite-suppressing effect and they both also have an impact upon glycaemic regulation (78). In contrast to the anorectic actions of PYY and GLP-1, ghrelin, produced primarily in the gastric fundus, stimulates appetite and energy intake. Circulating ghrelin levels increase during fasting and decrease post-prandially in proportion to the amount of ingested food (81). The known effect of RYGB on gut hormones is an increased level of circulating PYY and GLP-1 and a reduced level of circulating ghrelin, promoting a reduced appetite (78). Changes in several other gut hormones, in circulating bile acid composition and gut microbiota composition are also thought to be mechanisms behind the weight reduction after RYGB (78). 


\section{Roux-en-Y gastric bypass and women of fertile age}

Swedish data show a median weight loss of $38 \mathrm{~kg}$ and $31.9 \%$ weight loss one year after RYGB (75). The results are sustainable with $32.3 \%$ weight loss after two years and $28.4 \%$ weight loss after five years (75).

The median age for patients undergoing bariatric surgery in Sweden is 41 years. Women constitute $77 \%$ of all patients undergoing bariatric surgery in Sweden (82), in line with international figures (83). The IFSO global registry report from 2018 covers worldwide bariatric surgery from 51 countries; the average age for surgery is 42 years and $73.7 \%$ of patients are women (84). Hence, the majority undergoing bariatric surgery are women of fertile age.

Women are recommended not to become pregnant in the first 12 to 18 months after gastric bypass surgery in order to avoid suboptimal weight loss $(85,86)$. There is a postoperative increased risk of foetal complications such as preterm birth and small size for gestational age after bariatric surgery $(77,85,87-91)$. On the other hand, the procedure decreases obesity-related risks of gestational hypertension, maternal diabetes mellitus, foetal macrosomia and children being born large for gestational age $(83,87-89)$. The time to conception interval after surgery does not seem to affect the risks of gestational hypertension or diabetes or the incidence of prematurity according to some studies $(92,93)$. However; data are conflicting, another study showed a higher risk of prematurity if conception occurs within 2 years from surgery (94). The recommendation to avoid pregnancy for at least the first postoperative year still remains.

In summary; there are many women of fertile age going through RYGB and there is a great need for effective contraception during the postoperative period up to at least one year after surgery for these women.

\section{Roux-en-Y gastric bypass and the pharmacokinetics of drugs}

There are several potential changes in pharmacokinetics after RYGB that have different effects on different drugs.

1. The villi and microvilli, which constitute the vast surface area for absorption, have their highest concentration in the duodenum and proximal jejunum. This is the segment that is bypassed in RYGB, reducing the surface area for drug absorption (95).

2. Some drugs have extended-release formulations and as the intestinal transit time may be reduced by the bypass of part of the small intestine, these drugs may not have an adequate transit time for full dissolution and absorption (95).

3. Since most of the parietal cells, the hydrochloric acid producers, are located in the part of the stomach that has been bypassed, the $\mathrm{pH}$ of the 
stomach increases to $>4$ after RYGB. Some drugs require an acidic environment for dissolution, activation, or absorption.

In contrast, other drugs are degraded by acid; thus, the bioavailability is affected $(95,96)$.

4. Some drug transporters, metabolic enzymes and efflux pumps occur more frequently in the proximal small intestine, the area being bypassed. This may affect the possibility for some drugs to be absorbed (95). However, it is not always known for each drug where in the intestine the absorption ideally takes place. This is true for example with progestogens.

Absorption of desogestrel has been shown to occur in vitro in both the ileum and colon (47).

5. Some drugs, for example oral contraceptives, rely on first pass metabolism and enterohepatic recycling to maintain steady state blood levels. This procedure may be affected by the bypass and could lead to altered pharmacokinetic behaviour or unpredictable blood levels due to decreased contact with the intestine or altered mesenteric blood flow.

\section{Roux-en-Y gastric bypass and specific pharmacokinetic studies}

RYGB seems to have different effects on different drugs. A decrease in the AUC of different anti-depressive drugs, such as sertraline, duloxetine and escitalopram has been shown after RYGB (97-99).

No clinically relevant pharmacokinetic changes have been shown for venlafaxine, metoprolol, midazolam, caffeine, tolbutamide and omeprazole (100-102). A pharmacokinetic study of amoxicillin showed an increased exposure of the drug measured as AUC two months after RYGB compared with before (103). However, despite this increase, amoxicillin exposure was lower than reported for non-obese volunteers.

Thus, the effects of RYGB seem to affect the pharmacokinetics of different drugs in different ways.

\section{Specific background to the present studies}

\section{Contraceptive counselling to women with obesity and in relation to bariatric surgery (Paper I-II)}

Most studies regarding contraceptive use and continuation rates are undertaken on normal-weight women, or without distinction of BMI or other anthropomorphic measures of obesity. Currently, little is known about contraceptive use in women with obesity and nor is it known to what extent the recommendations concerning $\mathrm{CHC}$ use are followed. This is also true for women who have undergone bariatric surgery. 
The difference in follicular suppression and activity between normal-weight women and women with obesity could possibly cause differences in bleeding pattern which in turn could affect satisfaction and adherence to treatment.

The side effect profile, including poor bleeding control, has been described as one of the most important features of adherence to a contraceptive method (104). Progestin-only methods are more likely to induce bleeding disturbances (105107) and have been reported to have lower continuation rates (27). It is therefore important to study side effects in POP users with obesity, for which CHC is not primarily recommended.

More studies including women with obesity, with or without previous bariatric surgery, are needed in order to provide better information to this increasing group of women.

\section{Bariatric surgery and oral contraceptives (Paper III-IV)}

There is a lack of knowledge regarding the effect of RYGB on the absorption and pharmacokinetics of oral contraceptives. Previous studies have shown different results regarding the pharmacokinetics of progestins and oestrogens following jejunoileal bypass surgery. As early as 1976 Johansson et al. reported a lower serum concentration of NET and LNG in seven women after jejunoileostomy compared with non-operated normal-weight women (108). Andersen et al. compared the pharmacokinetics of D-norgestrel, estradiol and estrone in women who had undergone jejunoileal bypass. They found significantly higher D-norgestrel peak levels in the women in the operated group (109). Victor et al. found significantly lower plasma levels of LNG and lower but not significantly lower plasma levels of NET following jejunoileal bypass surgery compared with normal-weight women, which implies a reduced absorption of progestogens (110). These studies are of old age and all concern more extensive surgical methods that are no longer in use (111). Consequently, these results cannot be used to form a basis for appropriate contraceptive counselling to women following modern bariatric surgery such as RYGB. Due to this lack of studies concerning the pharmacokinetics of oral hormonal contraceptives to women after RYGB, the recommendations are to avoid oral contraceptives $(85,112,113)$. These recommendations, however, are based only on caution and not on evidence. There is a need for further studies concerning the pharmacokinetics of hormonal contraception and modern methods of bariatric surgery, in order to create a basis for evidence-based recommendations.

Based on this, the following hypotheses were formulated: 


\section{Hypotheses}

- Obese women more commonly discontinue or change contraceptive methods compared with normal-weight women.

- The most frequent oral contraceptive used by obese women in Sweden prior to and after gastric bypass is desogestrel $75 \mu \mathrm{g}$.

- The steady state serum concentration, measured as AUC of the active metabolite of desogestrel, etonogestrel, is decreased after Roux-en-Y gastric bypass surgery.

- The single dose serum concentration, measured as AUC of levonorgestrel from a combined oral contraceptive is reduced after RYGB in women who have reached a $\mathrm{BMI}<30$ compared to non-operated women in the same weight class. 


\section{Aims}

General aim

- To describe the pattern of contraceptive use in women with obesity and to contribute new knowledge that can improve contraceptive counselling for women who have undergone RYGB.

\section{Specific aims}

- To explore the prescription of different contraceptive methods to women with obesity and to compare the patterns of prescription and adherence to treatment in relation to normal-weight women (Paper I).

- To investigate whether women with obesity using hormonal contraceptives report more side effects and poorer bleeding control, compared with normal-weight women and, if so, whether these reported side effects result in more frequent contact with health care providers (Paper I).

- To describe how women undergoing RYGB perceive the contraceptive counselling they were given before the procedure, and to determine patterns of contraceptive use before and after surgery in these women (Paper II).

- To investigate whether RYGB affects the pharmacokinetics of oral desogestrel (etonogestrel) (Paper III).

- To investigate the oral LNG pharmacokinetics of women who underwent RYGB and reached a $\mathrm{BMI}<30$ and compare these with the LNG pharmacokinetics of BMI-matched non-operated women (Paper IV). 


\section{Material and methods}

A summary of the methods of the four studies is presented in Table 4 below.

\begin{tabular}{|c|c|c|c|c|}
\hline Study & I & II & III & IV \\
\hline Design & $\begin{array}{l}\text { Retrospective } \\
\text { cohort study }\end{array}$ & $\begin{array}{l}\text { Questionnaire- } \\
\text { based, cross- } \\
\text { sectional study }\end{array}$ & $\begin{array}{l}\text { Single centre, } \\
\text { open label, phase } \\
2 \\
\text { pharmacokinetic } \\
\text { study }\end{array}$ & $\begin{array}{l}\text { Multi-centre, open } \\
\text { label, phase } 2 \\
\text { pharmacokinetic } \\
\text { study }\end{array}$ \\
\hline Data collection & $2010-2014$ & 2010 & $\begin{array}{l}\text { Feb } 2014 \text { - May } \\
2016\end{array}$ & $\begin{array}{l}\text { June } 2016- \\
\text { February } 2018\end{array}$ \\
\hline $\begin{array}{l}\text { Data sources / } \\
\text { analytical method }\end{array}$ & $\begin{array}{l}\text { Medical records; } \\
\text { Obstetrix }^{\circledR} \text { and } \\
\text { Cosmic }^{\circledR}\end{array}$ & $\begin{array}{l}\text { Scandinavian } \\
\text { obesity surgery } \\
\text { registry, postal } \\
\text { questionnaire } \\
(2012)\end{array}$ & UPLC/MS-MS & UPLC/MS-MS* \\
\hline Subjects & $\begin{array}{l}371 \text { women with } \\
\text { obesity, 18-40 } \\
\text { years old }\end{array}$ & $\begin{array}{l}1000 \text { women, } 18- \\
45 \text { years old, who } \\
\text { had previously } \\
\text { undergone gastric } \\
\text { bypass surgery }\end{array}$ & $\begin{array}{l}\text { Nine women, 18- } \\
45 \text { years old, } \\
\text { undergoing } \\
\text { RYGB }^{* *} \text { and } \\
\text { using desogestrel } \\
75 \mu \mathrm{g}\end{array}$ & $\begin{array}{l}15 \text { women, } 18-40 \\
\text { years old, at least } \\
\text { one year after } \\
\mathrm{RYGB}^{* *} \text {. } \\
\mathrm{BMI}<30^{\#}\end{array}$ \\
\hline Controls & $\begin{array}{l}744 \text { normal- } \\
\text { weight women }\end{array}$ & No & No & $\begin{array}{l}15 \mathrm{BMI}^{\#} \text { matched } \\
\text { non-operated } \\
\text { women } 18-40 \\
\text { years old }\end{array}$ \\
\hline Exposures & $\begin{array}{l}\text { Prescribed } \\
\text { contraceptive } \\
\text { method BMI }\end{array}$ & $\begin{array}{l}\text { RYGB }^{* *} \text { during } \\
2010\end{array}$ & $\begin{array}{l}\text { Continuous use of } \\
\text { oral Desogestrel } \\
75 \mu \mathrm{g} \\
\left(\text { Cerazette }^{\circledR}\right) \text {. }\end{array}$ & $\begin{array}{l}\text { Single dose oral } \\
\text { levonorgestrel } \\
150 \mu \mathrm{g} \\
\left(\text { Neovletta }^{\circledR}\right) \text {. }\end{array}$ \\
\hline $\begin{array}{l}\text { Outcome } \\
\text { measures }\end{array}$ & $\begin{array}{l}\text { Adverse effects, } \\
\text { duration of } \\
\text { treatment, } \\
\text { reasons for } \\
\text { discontinuation, } \\
\text { bleeding pattern }\end{array}$ & $\begin{array}{l}\text { Previous (pre- } \\
\text { RYGB }^{* *} \text { ) and } \\
\text { present } \\
\text { contraceptive use, } \\
\text { contraceptive } \\
\text { counselling, } \\
\text { recommendations } \\
\text { regarding } \\
\text { pregnancy after } \\
\text { RYGB }^{* *}\end{array}$ & $\begin{array}{l}\text { Area under the } \\
\text { time } \\
\text { concentration } \\
\text { curve (AUC } 0-24 \mathrm{~h}) \\
\text { for etonogestrel } \\
8 \pm 6 \text { weeks before, } \\
12 \pm 2 \text { weeks } \\
\text { after, and } 52 \pm 2 \\
\text { weeks after }^{*} \text { RYGB }^{* *}\end{array}$ & $\begin{array}{l}\text { Area under the } \\
\text { time } \\
\text { concentration } \\
\left.\text { curve (AUC }{ }_{0-24 h}\right) \\
\text { for levonorgestrel } \\
\text { after } \\
\text { administration of } \\
\text { a single dose }\end{array}$ \\
\hline Statistics & $\begin{array}{l}\text { Descriptive } \\
\text { statistics, Chi- } \\
\text { squared tests }\end{array}$ & $\begin{array}{l}\text { Descriptive } \\
\text { statistics, Chi- } \\
\text { squared tests }\end{array}$ & $\begin{array}{l}\text { Descriptive } \\
\text { statistics, paired } \\
\text { Student's } t \text {-test }\end{array}$ & $\begin{array}{l}\text { Descriptive } \\
\text { statistics, } \\
\text { independent } t \text {-test }\end{array}$ \\
\hline
\end{tabular}

Table 4. Summary of the four studies included in the thesis.

${ }^{*}$ UPLC/MS-MS - ultra-performance liquid chromatography tandem mass spectrometry,

${ }^{* *}$ RYGB - Roux-en-Y gastric bypass, ${ }^{\#}$ BMI-Body mass index 


\section{Study populations, study design and outcomes}

\section{Study I (Paper I)}

\section{Study population}

We included in the study women aged 18-40 with BMI between $30-50 \mathrm{~kg} / \mathrm{m}^{2}$ who had visited the family planning units in the county of Östergötland, Sweden, at the Department of Obstetrics and Gynaecology, Linköping University Hospital, at least once during 2010. Every woman with obesity was matched with two normal-weight women (BMI between $19-25 \mathrm{~kg} / \mathrm{m}^{2}$ ) born on the same day or, if none were found, we matched with women born on the following day or days.

\section{Study design}

A retrospective cohort study was performed to investigate the prescription of different contraceptive methods to women with obesity, and to compare patterns of prescription and adherence to treatment in relation to normal-weight women a retrospective cohort study was performed.

Medical records were scrutinised from the period of 1 January 2010 to 31 December 2014.

In order to anonymise the study objects, all personal identification numbers were replaced by a number.

\section{$\underline{\text { Outcomes }}$}

From the Obstetrix ${ }^{\circledR}$ medical record system the retrieved variables were: year of birth, age, BMI at the beginning and at the end of the study period, other diseases, all contraceptive methods prescribed during the study period and the associated duration of treatment, adverse effects, reasons for discontinuation, and bleeding pattern. The total number of visits and total number of previous pregnancies were also retrieved. The information on prescribed contraceptives was verified with information from the pharmacological prescription module in Cosmic $^{\circledR}$. We distinguished between incident and prevalent users. An incident user was defined as a study object that had not used any type of contraception for at least the last six weeks at the start of the study period on 1 January 2010. A prevalent user was defined as a woman already using some type of contraception at the start of the study period on 1 January 2010.

Data from the medical records were converted into numerical variables and collated in Microsoft Excel ${ }^{\circledR} 2010$. The data were then transferred into IBM SPSS Statistics 24 (IBM New York, USA) for statistical analysis. 


\section{Study population}

SOReg provided names and personal identification numbers of 1000 women aged 18-45 years who had undergone RYGB in Sweden during 2010. We were able to retrieve correct addresses for 987 of these women.

\section{Study design}

We constructed a postal questionnaire comprising questions regarding educational level, smoking habits, pre- and postoperative weight, history of childbirth and pregnancies before and after RYGB. The questionnaire also contained questions on previous and present contraceptive use, contraceptive counselling in relation to RYGB and recommendations concerning avoidance of pregnancy after RYGB (Appendix 1).

The questionnaire was internally validated through a " think-aloud" cognitive interviewing technique (114). Six women who had all recently undergone RYGB answered the questionnaire orally, face to face. The women were asked to explain how they perceived the questions. All comments on the questionnaire were noted. This procedure identified some questions that needed remodelling. A postal questionnaire was sent to all included women (Appendix 1). Data on comorbidities were retrieved from SOReg. SOReg also provided preoperative data on smoking habits, weight and BMI, to validate the answers. The questionnaires were coded and after four weeks we sent a reminder to those who had not answered. A second reminder was sent after another four weeks. All the questionnaires were optically scanned into a computer after a manual confirmation that the first 10 scanned questionnaires had been correctly scanned.

\section{Outcomes}

The main outcome measures were: contraceptive methods used before and after RYGB, contraceptive counselling before RYGB and how it was perceived, and what type of recommendations were given regarding pregnancy after surgery.

\section{Study III and IV (Paper III and IV)}

\section{Study populations}

In study III, our aim was to have 12 women complete the whole study protocol. Since we expected some drop outs we planned to include 14 women.

We included Swedish-speaking women aged 18-45 years who were scheduled for RYGB surgery at the Department of Surgery at the Vrinnevihospital in Norrköping. To be able to evaluate steady state pharmacokinetics they had been taking $75 \mu \mathrm{g}$ of desogestrel for at least one month before inclusion. The women also needed to be willing to continue using desogestrel for the first postoperative year (paper III). 
Study IV was performed at the University Hospital of Linköping and at the Clinical Trials centre at the Department of Obstetrics and Gynecology at Danderyd Hospital, Karolinska Institutet, Stockholm. Fifteen Swedish-speaking women aged 18-40 years who had previously undergone RYGB surgery and reached a BMI $<30$ were included. The women that were included in Linköping, were recruited by means of a letter with an invitation to participate in the study. SOReg provided personal identification numbers to women who had undergone surgery in Östergötland. The women that were included at the Department of Surgery at Danderyd Hospital (Stockholm) were recruited through local advertising. Fifteen Swedish-speaking BMI-matched women aged 18-40 years with no previous history of RYGB were included as a control group (paper IV). The control group were recruited from both centres through local advertising at the hospitals.

\section{Study design}

Study III and IV were open label, phase-2 pharmacokinetic studies. Study III was a single centre study and study IV was a multi-centre study.

Exclusion criteria (paper III and IV) were: recent pregnancy (within the past three months), breast-feeding and smoking on a daily basis. Use of the progestogen-only injectable (depotmedroxyprogesteroneacetate) within the past 12 months, other hormonal contraception four weeks prior to inclusion or a medical history of bilateral oophorectomy, hysterectomy, undiagnosed vaginal bleeding or lactose intolerance were also considered as exclusion criteria. Women using medications or substances known to affect the cytochrome P450 system, including for example antiepileptic drugs, were ineligible, as were women regularly consuming grapefruit juice and St John's wort. The women of study III (paper III) were not allowed to start the recommended preoperative low-calorie diet before inclusion or the first blood sampling occasion. This diet changes the metabolism and it might have affected the results.

All participants had a normal gynaecological examination including normalappearing ovaries on a baseline sonogram with a $7.5-\mathrm{MHz}$ transvaginal probe (papers III and IV).

\section{Procedure and exposures}

The research nurses at the Department of Clinical Pharmacology, University Hospital of Linköping (paper III and IV) and at the Clinical Trials Centre, Department of Obstetrics and Gynecology, Danderyds Hospital, Sweden (paper IV) performed blood sampling in a standardised manner. Blood samples were taken at $0,0.5,1,1.5,2,2.5,3,4,6,8,12$ and 24 hours after ingesting one dose of desogestrel $75 \mu \mathrm{g}$ (Cerazette, MSD, Sollentuna, Sweden) provided by the hospital research pharmacy (lot 996138) (paper III) or one dose of $0.03 \mathrm{mg}$ EE and $0.15 \mathrm{mg}$ of LNG (Neovletta, Bayer, Berlin, Germany) provided by the 
hospital research pharmacy (lot 54471c) (paper IV). All patients ingested the study medication at 8.00 in the morning. During the 24 -hour period of blood sampling, all study participants were served standardised food according to a dietician's recommendations.

For the women included in study III (paper III) the first blood sample collection was performed $8 \pm 6$ weeks preoperatively. One patient had the first sampling performed outside this time limit, due to a seven-month postponement of her surgery. The second 24-hour blood sampling took place $12 \pm 2$ weeks postoperatively and the third $52 \pm 2$ weeks postoperatively, both with the exact same procedure as the first blood sampling. For study IV (paper IV) there was only one blood sampling period per patient.

On each occasion, weight and BMI were measured and information on general health status and medication was collected. We used the same weight scale for all body weight measurements. Blood samples were centrifuged after 30 minutes at $1970 \mathrm{~g}$ for 10 minutes and the plasma samples were then stored at $70^{\circ} \mathrm{C}$ until the time of analysis.

\section{Outcomes}

The main outcome measure was $\mathrm{AUC}_{(0-24 \mathrm{~h})}$ (papers III and IV).

Peak concentrations $\left(C_{\max }\right)$ and time to maximum concentration $\left(T_{\max }\right)$ values were taken directly from the original data of the UPLC/MS-MS results. For the pharmacokinetic analyses, serum concentration values of etonogestrel (paper III) and levonorgestrel (paper IV) for each participant were fitted using a noncompartmental approach. The non-compartmental approach is generally chosen when the primary goal is to determine the degree of exposure of a drug, i.e. the AUC and other pharmacokinetic parameters, following drug administration. Other methods, such as the nonlinear regression analysis, require the assumption of a specific compartmental model for either drug or metabolite (115).

We calculated AUC from $t_{0}$ to $t_{24}$ using linear trapezoidal approximation. The total AUC was extrapolated from the slope of the last four measurements in the concentration curve (paper IV). Elimination half-lives $\left(t^{1} / 2\right)$ for etonogestrel and levonorgestrel were calculated as $\ln 2 / \mathrm{kz}$, in which $\mathrm{kz}$ is a parameter describing the linear terminal slope of the log concentrations of etonogestrel. The apparent oral clearance of etonogestrel was calculated as dose/AUC.

\section{Data sources}

\section{Electronic medical records}

Data for paper I were collected from the computerised medical record system Obstetrix ${ }^{\circledR}$ (Cerner AB Sweden) and Cosmic ${ }^{\circledR}$ (Cambio Health Care systems, Sweden). Obstetrix is used in most counties of Sweden as a medical record 
concerning family planning and health care during and shortly after pregnancies. Cosmic is the general medical record system for the county of Östergötland.

\section{Register}

The Scandinavian Obesity Surgery registry (SOReg) is a nationwide register that covers bariatric surgery in Sweden. All 38 bariatric surgery clinics in Sweden report to SOReg. The register started in 2007 and is updated once every year. The register was used for recruiting patients for study II and IV (paper II and $I V)$.

\section{Pharmacokinetic analyses}

At the time of planning studies III and IV, there was no available laboratory in Sweden that performed measurements of serum concentration of ENG and LNG. An ultra-performance liquid chromatography/tandem mass spectrometry (UPLC/MS-MS) method was developed in collaboration with the Department of Clinical Pharmacology at the University Hospital of Linköping from a method previously described by Seaves et al. (116) (Appendix 2).

Briefly, UPLC has the ability to separate, identify and quantitate the compounds that are present in any sample that can be dissolved in a liquid. The patient sample is dissolved and introduced into the stream of the mobile phase (consisting of $0.1 \%$ formic acid in $10 \mathrm{mM}$ ammonium formiate and water $\mathrm{A}$, and methanol B) in small amounts using a high-pressure pump. Acetonitrile and methanol were used as solvents for our samples. The pump produces a high pressure which is needed to filter the sample solution through the column of UPLC. We used a C18 column. The speed of movement differs between different samples, due to differences in the interactions between the sample components and the adsorbent inside the column. For comparison in the analyses, other samples can be added, such as a standard solution of ENG or LNG or quality control solution. As a result, the components of the sample are separated. At the end of the column, the sample is collected and then ionised in a metal capillary (the interface). The interface is needed since the chromatography and the mass spectrum devices are incompatible. The interface transfers the maximum amount of analyte into the mass spectrometer in a gas phase. This is achieved through different methods of ionisation. The MS measures the massto-charge ratio $(\mathrm{m} / \mathrm{z})$ of ions. The detector measures and amplifies the ion current to calculate the abundance of each ion. A data system records, processes, stores and displays data in a computer to generate a mass spectrum chromatogram that the human eye can interpret (Figure 3). 


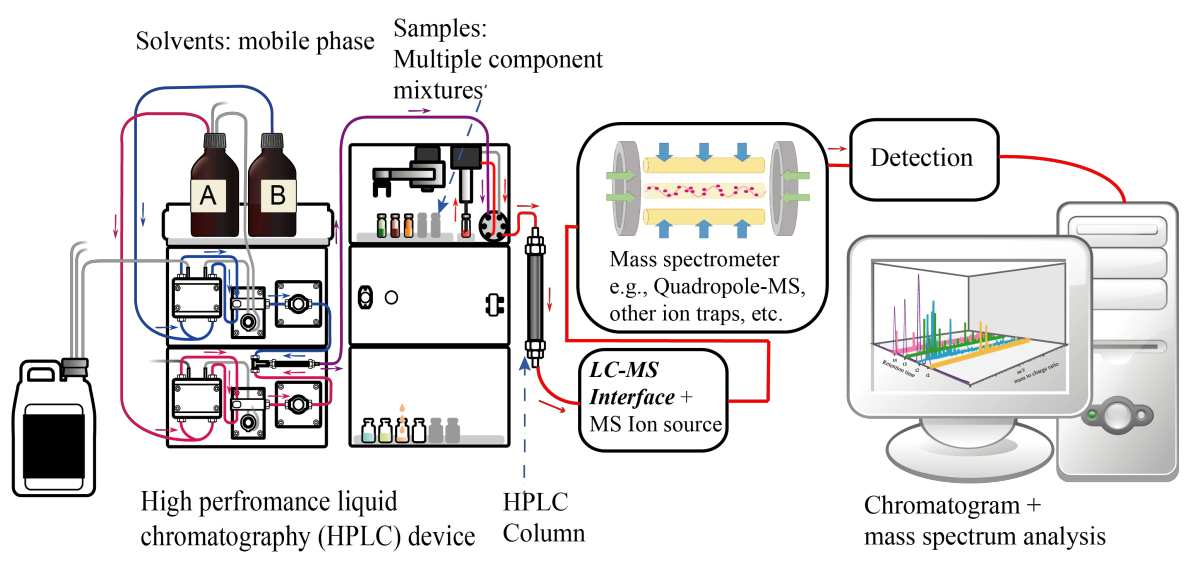

Figure 3. Schematic figure over liquid chromatography mass spectrometry technique. (Picture published by permission of Wikimedia.org. By Daniel Norena-Caro - Created in Illustrator C6, CC0, https://en.wikipedia.org/w/index.php?curid=53483681 )

\section{Statistics}

\section{Sample size calculation}

For study I (paper I) we performed a sample size calculation based on the assumption that $15 \%$ of the normal-weight women would discontinue or change their contraceptive method during the first year of the study period. We considered a $50 \%$ higher rate of discontinuation among women with obesity to be clinically significant, i.e. that $22.5 \%$ of the women with obesity would discontinue or change method within one year. To detect this difference with $80 \%$ power and a significance level of 0.05 we needed to include 300 women with obesity and 600 normal-weight women. The number of women with obesity who were found to have had at least one contact with the family planning unit during 2010 only slightly exceeded this number. We therefore decided to include all women with obesity together with twice as many normalweight women in the study (paper I).

For study II no sample size calculation was made since it was a descriptive study (paper II).

For study III, 12 participants was considered to be an adequate number when comparing with similar studies (56). No sample size calculation was made (paper III). 
It has been shown that COCs containing $0.10 \mathrm{mg}$ LNG yield acceptable inhibition of ovulation (117). The AUC after a single dose of these COCs is approximately $40-50 \%$ lower than for a COC containing $0.15 \mathrm{mg}$ LNG (118, 119). Such a difference in AUC seems acceptable. Consequently, the sample size for study IV (paper IV) was set after estimating that a clinically relevant difference between the groups would be 50\% lower AUC in the RYGB group. To show this difference with $80 \%$ power and a p-value of 0.05 , the sample size was estimated at 15 in each group. To compensate for inaccuracies in our estimation we decided to include 30 women in each group, and to perform a half way interim analysis after inclusion of 15 women in each group.

\section{Descriptive statistics}

Mean and standard deviation (SD) or median and range were used for continuous variables (paper I, II, III and IV). For categorical variables, numbers and percentages were presented (paper III).

\section{Analyses of outcomes}

When estimating differences of outcomes between women with obesity and normal-weight women (paper I) and comparing differences between pre- and postoperative outcomes (paper II), Chi-squared test was used.

For study III each patient served as her own control (paper III). The preoperative weight and pharmacokinetic variables were compared separately with the corresponding variables at each postoperative sampling by using a paired Student's $t$-test. Since the standard deviation was small in relation to the mean, the data were found to be normally distributed. For study IV the data showed normal distribution and the groups were compared using an independent $t$-test (paper IV). The results of papers III and IV were verified with a nonparametric signed-rank test.

\section{Ethical approval and considerations}

The studies in this thesis were approved by the Regional Ethical Review Board in Linköping, Sweden (Study I; Dnr 2017/180-31, Study II; Dnr 2011/363-31, Study III; Dnr 2013/395-32 and Study IV; Dnr 2016/22-31).

Written informed consent was signed by all participants of studies III and IV. The participants of study II indirectly consented by replying to the questionnaire.

Study I was performed without the participants' informed consent. In certain cases of research on personal health with data from medical records, informed consent is typically not required. The aim was to describe the contraceptive use and side effects of contraceptives in order to improve contraceptive counselling 
for women with obesity. The Swedish Ethical Review Authority does not require written informed consent in such studies. The retrospective design of the study was non-interventional, and the study did not affect the health of the study participants.

\section{Approval of the Medical Products Agency}

Studies III and IV were approved by the Medical Products Agency (EudraCT 2012-005797-58 and 2014-004677-17). 


\section{Results}

\section{Contraception in women with obesity}

\section{Prescription, side effects and discontinuation of contraceptives (paper I)}

The study population consisted of 1115 women in total; 371 with obesity and 744 normal-weight women. For the group of women with obesity, median BMI was 33 compared to 22 in the control group.

The number of different prescribed contraceptive methods during the study period was similar in both groups, as was duration of use of first contraceptive method and number of contacts with the clinic during the study. The proportion of incident users was also similar in both groups.

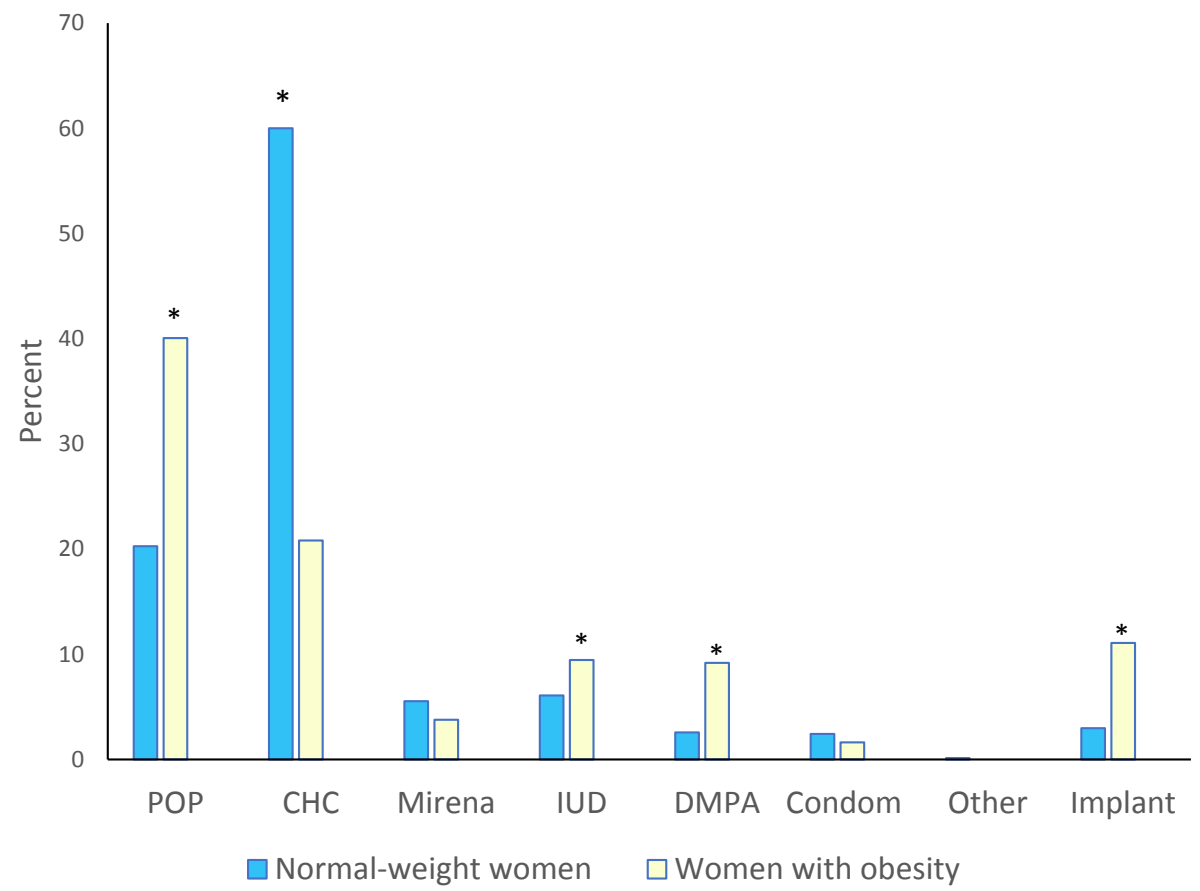

Figure 4. First prescribed contraceptive method during the study period. Normal-weight women $\mathrm{n}=739$. Women with obesity $\mathrm{n}=370$. $\mathrm{POP}=$ progestin-only pills, $\mathrm{CHC}=$ combined hormonal contraceptives, $\mathrm{IUD}=$ intrauterine device, $\mathrm{DMPA}=$ depo medroxyprogesterone acetate (injection). $*=p<0,05$. Chi-square test was used. 
Progestin-only pills were the most common contraceptive method prescribed to women with obesity. Forty-four percent of women with obesity were prescribed POP compared with $20 \%$ of normal-weight women $(p=0.001)$. Combined hormonal contraception was the most common contraception method prescribed to normal-weight-women. Among women with obesity $20 \%$ were prescribed CHC. Use of Cu-IUD, implant and DMPA were significantly more common in women with obesity (Figure 4).

There was no significant difference in the number of different prescribed contraceptive methods between the groups during the five-year study period. The duration of use of the first method did not significantly differ between the groups. Discontinuation of any method over the whole five-year study period was more common among incident than prevalent users, at $88 \%$ vs $68 \%$ respectively $(p<0.001)$. Thirty-three per cent of the women with obesity discontinued within the first year compared with $25 \%$ of the normal-weight women $(p=0.003)$. When stratified for incident and prevalent users, the difference remained significant among incident users only ( $46 \%$ vs. $34 \%$ respectively, $\mathrm{p}=0.029$ ) (Table 5 ).

\begin{tabular}{|l|l|l|l|l|}
\hline & \multicolumn{2}{|c|}{ Incident $n=317$} & \multicolumn{2}{c|}{ Prevalent $n=798$} \\
\hline & $\begin{array}{l}\text { Normal-weight } \\
\text { women } n=207\end{array}$ & $\begin{array}{l}\text { Women with } \\
\text { obesity } n=110\end{array}$ & $\begin{array}{l}\text { Normal-weight } \\
\text { women } n=537\end{array}$ & $\begin{array}{l}\text { Women with } \\
\text { obesity } n=261\end{array}$ \\
\hline $\begin{array}{l}\text { Discontinuation } \\
\text { first year }\end{array}$ & $70(34 \%)$ & $51(46 \%) *$ & $113(21 \%)$ & $71(27 \%)$ \\
\hline
\end{tabular}

Table 5. Discontinuation of contraceptive method within in the first year of the study period among incident and prevalent users. ${ }^{*} \mathrm{p}=0.029$ between incident women with obesity compared with incident normal-weight women. Chi-square test was used for statistical analysis.

Within the whole population, POP users $(n=313)$ were more likely than CHC users $(\mathrm{n}=521)$ to discontinue within the first year $(35 \%$ vs. $18 \% \mathrm{p}<0.001)$. The difference remained significant when stratified for incident and prevalent users (Table 6). Among POP users, women with obesity and normal-weight women showed equal discontinuation rates.

\begin{tabular}{|l|l|l|l|l|}
\hline & \multicolumn{2}{|c|}{ Incident user $n=221$} & \multicolumn{2}{c|}{ Prevalent user $n=613$} \\
\hline & POP $n=111$ & CHC $n=110$ & POP $n=202$ & CHC $n=411$ \\
\hline $\begin{array}{l}\text { Discontinuation } \\
\text { first year }\end{array}$ & $61(55 \%)$ & $37(34 \%) *$ & $47(23 \%)$ & $58(14 \%) * *$ \\
\hline
\end{tabular}

Table 6. Discontinuation of POP - progestin-only pill use or CHC - combined hormonal contraception use within in the first year of the study period among incident and prevalent users. ${ }^{*} \mathrm{p}=0.001$ between incident POP users vs incident CHC users, ${ }^{* *} \mathrm{p}=0.005$ between prevalent POP vs $\mathrm{CHC}$ users. Chi-square test was used for statistical analysis. 
The most commonly declared reason for discontinuation was bleeding disturbance. This was more common among women with obesity than normalweight women $40(14.7 \%)$ vs $53(9.6 \%)(p=0.008)$. Information regarding reasons for discontinuation was missing in $48 \%$ of all women, with no difference between the groups.

POP users reported significantly more irregular bleedings and amenorrhea than CHC users $(p<0.001)$. There was no significant difference in reported bleeding pattern between normal-weight women and women with obesity using either CHCs or POPs. Information regarding bleeding pattern was missing in $44 \%$ of POP users and $72 \%$ of $\mathrm{CHC}$ users.

Sub-analyses of the women with obesity with BMI classes II-III $(n=107)$ showed a $56.1 \%(\mathrm{n}=60)$ prescription rate of POP to this group as the first contraceptive method. Three women were using CHC in this group. In the group of women with BMI class I $(n=264), 28 \%(n=74)$ were CHC users, whereof 88 $\%$ were prevalent users. In this group, $39 \%(\mathrm{n}=103)$ were prescribed POP as their first contraceptive method.

During the study period, $24 \mathrm{CHC}$ users (32\%) in BMI class I group discontinued their use because the prescriber considered the woman's BMI to be a contraindication to $\mathrm{CHC}$ use.

\section{Contraceptive use in women in relation to RYGB (paper II)}

Questionnaires were sent to 987 women who had undergone RYGB during 2010. After two reminders we received 563 answers, corresponding to a response rate of $57 \%$. The median age of the responders was 36 years, the median preoperative BMI was $43.6 \mathrm{~kg} / \mathrm{m}^{2}$ and the median BMI at the time of answering the questionnaire was $27.1 \mathrm{~kg} / \mathrm{m}^{2}$.

Sixty-seven percent used some kind of contraceptive method preoperatively, and $80 \%$ of these were satisfied with their method.

The most commonly used contraceptive method in women before RYGB was the LNG intrauterine device (15.3\%). As a group, longer-acting reversible contraceptives, especially IUDs, were more common than short-acting hormonal contraceptives ( $32.7 \%$ vs $24.2 \%$ ) before surgery. Preoperatively, $7.6 \%$ used COCs and $15.5 \%$ used POPs. One to two years after surgery, $28.8 \%$ used longer-acting contraceptives and $11.1 \%$ used short-acting contraceptives. More than one year after surgery, $9.4 \%$ were still using oral contraceptives (Table 7). 
Almost every fourth woman (24.8\%) actively stated that she had not received any advice to avoid pregnancy postoperatively, and $14.8 \%$ did not remember whether they had received such advice or not. The remaining $60.4 \%$ had received advice to avoid pregnancy for between 12 to 24 months postoperatively (Table 7).

During the first postoperative year, $29.9 \%$ did not use any contraception. At the time of answering the questionnaire $25 \%$ had become pregnant and $12 \%$ were actively trying to become pregnant.

\begin{tabular}{|c|c|c|c|c|}
\hline Contraceptive method $^{\mathrm{a}}$ & $\begin{array}{c}12 \text { months } \\
\text { before } \\
(n=563) \\
n(\%)\end{array}$ & $\begin{array}{c}12 \text { months } \\
\text { after } \\
(n=563) \\
n(\%)\end{array}$ & $\begin{array}{c}1-2 \text { years after } \\
(n=563) \\
n(\%)\end{array}$ & Sign $^{b}$ \\
\hline $\begin{array}{l}\text { Short-acting contraceptives } \\
\text { Any oral contraceptive } \\
\text { COC } \\
\text { Desogestrel-only pill } \\
\text { Other POP } \\
\text { Vaginal Ring } \\
\text { Patch }\end{array}$ & $\begin{array}{l}130(23.1) \\
43(7.6) \\
59(10.5) \\
28(5.0) \\
6(1.1) \\
0\end{array}$ & $\begin{array}{l}87(15.5) \\
29(5.2) \\
46(8.2) \\
12(2.1) \\
13(2.3) \\
5(0.9)\end{array}$ & $\begin{array}{l}53(9.4) \\
22(3.9) \\
28(5.0) \\
3(0.5) \\
7(1.2) \\
3(0.5)\end{array}$ & $\begin{array}{c}p=0.001 \\
n s \\
n s \\
p=0.01 \\
n s\end{array}$ \\
\hline $\begin{array}{l}\text { Long-acting contraceptives } \\
\text { Implant } \\
\text { LNG-IUS }^{* * *} \\
\text { IUD }^{\#} \\
\text { Injection }\end{array}$ & $\begin{array}{c}21(3.7) \\
86(15.3) \\
77(13.7) \\
34(6.0)\end{array}$ & $\begin{array}{c}23(4.1) \\
104(18.5) \\
61(10.9) \\
32(5.7)\end{array}$ & $\begin{array}{c}14(2.5) \\
108(19.2) \\
40(7.1) \\
29(5.2)\end{array}$ & $\begin{array}{l}n s \\
n s \\
n s \\
n s\end{array}$ \\
\hline \begin{tabular}{|l|} 
Condom \\
None
\end{tabular} & $110(19.5)$ & $\begin{array}{l}109(19.4) \\
168(29.9)\end{array}$ & $\begin{array}{c}\frac{78(13.7)}{210(37.2)} \\
\end{array}$ & $\begin{array}{l}n s \\
n s\end{array}$ \\
\hline
\end{tabular}

Table 7. Contraceptive methods used before and after surgery

${ }^{a}$ Participants could choose more than one option

${ }^{\mathrm{b}} 12$ months prior to surgery vs 12 months after surgery. Chi-square test

${ }^{*} \mathrm{COC}$ - Combined oral contraception, ${ }^{* *} \mathrm{POP}$ - progestin-only pill, ${ }^{* * *}$ LNG-IUS - Levonorgestrel intrauterine system, ${ }^{\#}$ IUD - Copper intrauterine device Chi-square test was used for statistical analysis. 
When selecting the women of BMI classes II-III from paper I and comparing with the preoperative results of women from paper II, the contraceptive use differed between the groups (Table 8). The data selections for the papers are from the same year (2010).

\begin{tabular}{|c|c|c|}
\hline Contraceptive method & $\begin{array}{c}\text { Obesity classes II-III } \\
(n=107) \\
n(\%) \\
\end{array}$ & $\begin{array}{c}12 \text { months before RYGB *a } \\
(n=563) \\
\text { n }(\%) \\
\end{array}$ \\
\hline $\begin{array}{c}\text { Short-acting contraceptives } \\
\text { CHC }^{* *} \\
\text { POP }^{\text {**** }}\end{array}$ & $\begin{array}{c}3(2.8) \\
60(56.1)\end{array}$ & $\begin{array}{c}49(8.7) \\
87(15.5)\end{array}$ \\
\hline $\begin{array}{l}\text { Long- acting contraceptives } \\
\text { Implant } \\
\text { LNG-IUS }^{\#} \\
\text { IUD }^{\circ} \\
\text { Injection }\end{array}$ & $\begin{aligned} 12 & (11.2) \\
5 & (4.7) \\
13 & (12.1) \\
13 & (12.1)\end{aligned}$ & $\begin{array}{l}21(3.7) \\
86(15.3) \\
77(13.7) \\
34(6.0)\end{array}$ \\
\hline Condom & $1(0.9)$ & $110(19.5)$ \\
\hline None & 0 & $182(32.3)$ \\
\hline
\end{tabular}

Table 8. Contraceptive use in women with BMI class II-III in papers I and II.

${ }^{a}$ participants could choose more than one option

*RYGB - Roux-en-Y gastric bypass, ${ }^{* *} \mathrm{CHC}$ - combined hormonal contraception, ${ }^{* * *} \mathrm{POP}$ - progestinonly pill, ${ }^{\#}$ LNG-IUS - levonorgestrel intrauterine system, ${ }^{\circ}$ IUD - copper intrauterine device

\section{Pharmacokinetics of oral progestins in relation to RYGB}

\section{Pharmacokinetics of etonogestrel}

Between February 2014 and May 2016, a total of 25 women were eligible for enrolment. Eleven women were not interested in participating. We included 14 patients, and nine women completed the study.

All patients had significant postoperative weight loss as compared with their baselines at each time point post-surgery (Table 9).

There were intra-individual differences in AUC before vs. after RYGB (figure 5 ), but the mean plasma concentration time curves were unaffected (figure 6). Etonogestrel exposure ( $\mathrm{AUC}_{0-24 \mathrm{~h}}, \mathrm{C}_{\max }, \mathrm{T}_{\max }, \mathrm{C}_{24 \mathrm{~h}}$, terminal half-lives $(\mathrm{t} \mathrm{t} / 2)$, or apparent oral clearances of etonogestrel $\left(\mathrm{CL}_{\text {oral }}\right)$ ), were not significantly altered after RYGB, except for a significantly higher $\mathrm{C}_{\max } 12$ months after RYGB compared to preoperatively $(0.817 \mathrm{ng} / \mathrm{ml}$ vs $0.590 \mathrm{ng} / \mathrm{ml}, p=0.024)$ (Table 9). 


\begin{tabular}{|c|c|c|c|c|}
\hline & $\begin{array}{l}8 \pm 6 \text { weeks before } \\
\text { RYGB } \\
(n=10)\end{array}$ & $\begin{array}{l}12 \pm 2 \text { weeks after } \\
\operatorname{RYGB}(n=10)\end{array}$ & $\begin{array}{l}52 \pm 2 \text { weeks } \\
\text { after } \operatorname{RYGB}(n=9)\end{array}$ & p-value \\
\hline $\begin{array}{l}\text { Age (years) } \\
\text { Median (range) }\end{array}$ & $35(22-41)$ & & & \\
\hline $\begin{array}{l}\mathrm{BMI}\left(\mathrm{kg} / \mathbf{m}^{2}\right) \\
\operatorname{Mean} \pm \mathrm{SD} \\
\operatorname{Min}-\mathrm{max}\end{array}$ & $\begin{array}{l}40.5 \pm 4.4 \\
34.8-50.6\end{array}$ & $\begin{array}{l}34.2 \pm 4.8 \\
29.2-46\end{array}$ & $\begin{array}{l}29.0 \pm 4.8 \\
24.5-40.2\end{array}$ & $<0.0001^{*}$ \\
\hline $\begin{array}{l}\text { Weight (kg) } \\
\text { Mean } \pm \text { SD } \\
\text { Min-Max } \\
\end{array}$ & $\begin{array}{l}111.3 \pm 15.5 \\
97.7-144.5\end{array}$ & $\begin{array}{l}93.8 \pm 15.5 \\
81.1-131.3 \\
\end{array}$ & $\begin{array}{l}78.9 \pm 14.9 \\
60.3-114.7 \\
\end{array}$ & $<0.0001^{*}$ \\
\hline $\begin{array}{l}\text { Weight loss (kg) } \\
\text { Median } \\
\text { Range } \\
\end{array}$ & & $\begin{array}{l}16.9 \\
12.3-22.2 \\
\end{array}$ & $\begin{array}{l}30.8 \\
19.3-37.7 \\
\end{array}$ & \\
\hline $\begin{array}{l}\text { Weight loss (\%) } \\
\text { Median } \\
\text { Range } \\
\end{array}$ & & $\begin{array}{l}16.2 \\
9.1-19.4\end{array}$ & $\begin{array}{l}28.4 \\
19.7-38.5 \\
\end{array}$ & \\
\hline $\begin{array}{l}\text { AUC }_{0-24 h}(\mathbf{n g} * \mathrm{~h} / \mathrm{ml}) \\
\text { Mean } \pm \text { SD } \\
\text { Min-max }\end{array}$ & $\begin{array}{l}6.097 \pm 1.49 \\
3.776-7.895\end{array}$ & $\begin{array}{l}6.119 \pm 1.56 \\
3.772-8.589\end{array}$ & $\begin{array}{l}6.096 \pm 1.41 \\
4.237-8.755\end{array}$ & $n s$ \\
\hline $\begin{array}{c}C_{\max }(\mathrm{ng} / \mathrm{ml}) \\
\text { Mean } \pm \mathrm{SD} \\
\text { Min-max } \\
\end{array}$ & $\begin{array}{l}0.590 \pm 0.236 \\
0.394-1.137 \\
\end{array}$ & $\begin{array}{l}0.633 \pm 0.113 \\
0.486-0.837 \\
\end{array}$ & $\begin{array}{l}0.817 \pm 0.163 \\
0.513-1.064 \\
\end{array}$ & $0.024 * *$ \\
\hline $\begin{array}{c}C_{24 h}(\mathrm{ng} / \mathrm{ml}) \\
\text { Mean } \pm \text { SD } \\
\text { Min-Max } \\
\end{array}$ & $\begin{array}{l}0.187 \pm 0.051 \\
0.128-0.258 \\
\end{array}$ & $\begin{array}{l}0.176 \pm 0.063 \\
0.091-0.279 \\
\end{array}$ & $\begin{array}{l}0.154 \pm 0.068 \\
0.066-0.285 \\
\end{array}$ & $n s$ \\
\hline $\begin{array}{l}\mathbf{T}_{\max }(\mathbf{h}) \\
\text { Median } \\
\text { Range }\end{array}$ & $\begin{array}{l}1.5 \\
1-4\end{array}$ & $\begin{array}{l}1 \\
1-2\end{array}$ & $\begin{array}{l}1 \\
1-1.5\end{array}$ & $n s$ \\
\hline $\begin{array}{l}t_{1 / 2} \text { (hours) } \\
\text { Mean } \pm \text { SD }\end{array}$ & $29.2 \pm 5.4$ & $25.8 \pm 9.4$ & $23.0 \pm 8.1$ & $n s$ \\
\hline $\begin{array}{c}\mathrm{CL}_{\text {oral }}(\mathrm{L} / \mathrm{h}) \\
\text { Mean } \pm \mathrm{SD}\end{array}$ & $13.1 \pm 3.5$ & $13.1 \pm 3.5$ & $12.9 \pm 2.9$ & $n s$ \\
\hline $\begin{array}{c}\text { SHBG }(\mathbf{n g} / \mathbf{m l}) \\
\text { Mean } \pm \text { SD }\end{array}$ & $28.17 \pm 12.82$ & $55.80 \pm 20.94$ & $76.62 \pm 24.79$ & $<0.0001^{*}$ \\
\hline
\end{tabular}

Table 9. Demographic and clinical characteristics and pharmacokinetic parameters of etonogestrel in nine patients before and at two occasions after RYGB (Roux-en-Y gastric bypass.

$\mathrm{AUC}_{0-24 \mathrm{~h}}=$ area under the serum concentration time curves, $\mathrm{C}_{\max }=$ peak serum concentrations, $\mathrm{C}_{24 \mathrm{~h}}=$ serum concentration $24 \mathrm{~h}$ after ingesting dose of etonogestrel, $\mathrm{T}_{\max }=$ time to peak serum concentrations, $\mathrm{t}_{1 / 2}=$ terminal half-lives of etonogestrel, $\mathrm{CL}_{\text {oral }}=$ apparent oral clearance of etonogestrel, $\mathrm{SHBG}=$ sex hormone-binding globulin

* $52 \pm 2$ weeks after RYGB and $12 \pm 2$ weeks after RYGB vs. $8 \pm 6$ weeks before RYGB

** $52 \pm 2$ weeks vs. $8 \pm 6$ weeks before RYGB

${ }^{\circ}$ Percentage of weight in kilograms lost

Paired Student's $t$-test were used for statistical analysis 


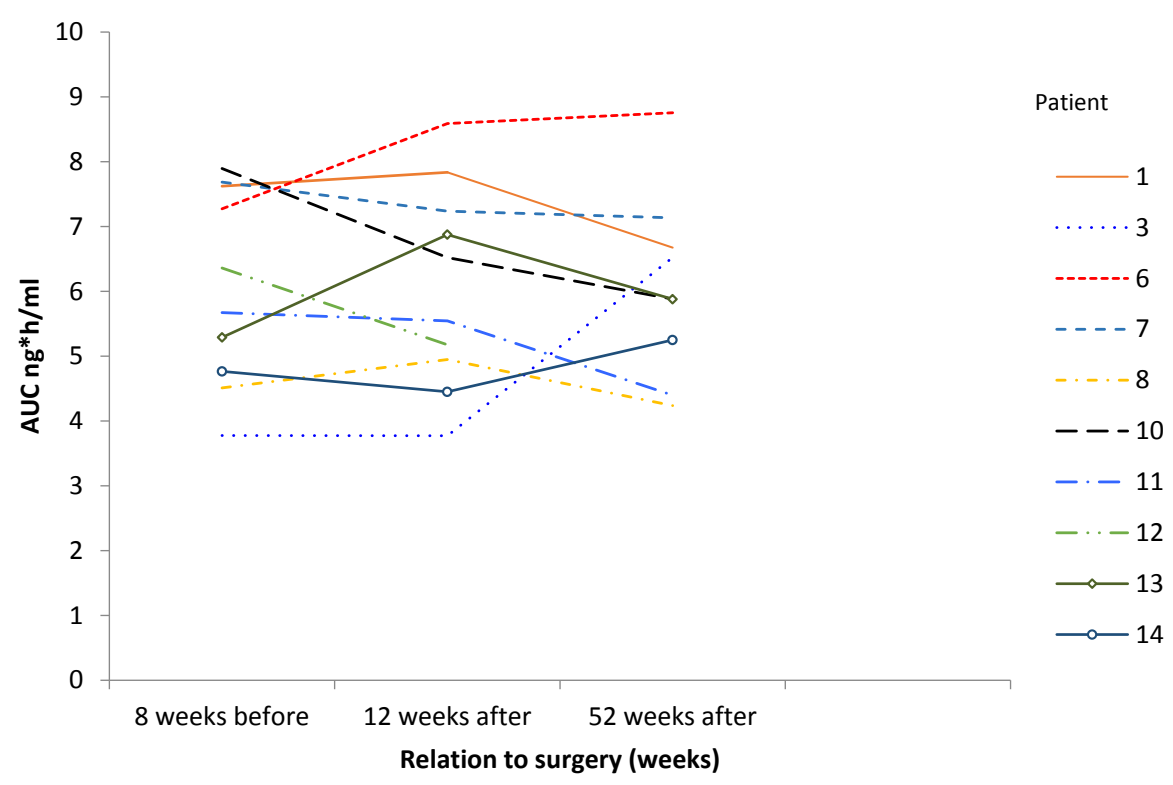

Figure 5. Individual values for area under the etonogestrel serum concentration-time curve (AUC) from 0-24 hours before ( $8 \pm 6$ weeks) and after ( $12 \pm 2$ weeks and $52 \pm 2$ weeks) Roux-en-Y gastric bypass (RYGB) surgery for each of the 10 study patients.

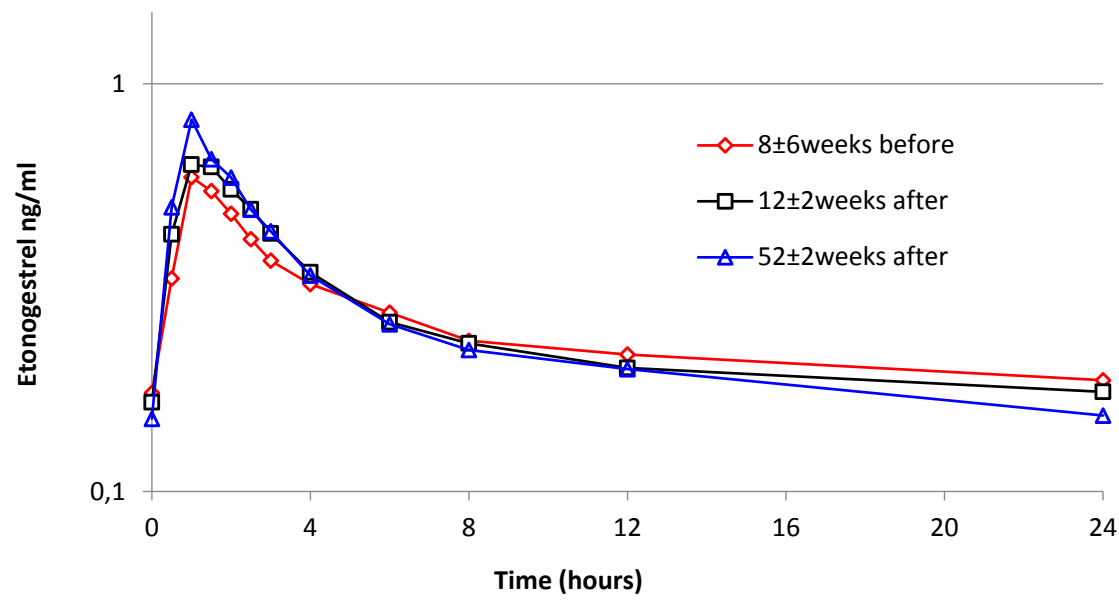

Figure 6. Mean values for the time course of etonogestrel plasma concentration from 0-24 hours for the study patients $8 \pm 6$ before, $12 \pm 2$ weeks and $52 \pm 2$ weeks after Roux-en-Y gastric bypass (RYGB) surgery. 


\section{Pharmacokinetics of levonorgestrel}

Between June 2016 and February 2018, a total of 15 women were included in each study group. When performing the interim analysis, no significant differences either in AUC or in $\mathrm{C}_{\max }$ between the groups were found. With these findings, the inclusion was considered satisfactory.

The groups were comparable in clinical characteristics such as median age, weight and BMI. (Table 10). When comparing all the pharmacokinetic parameters between the groups we found no significant differences (Table 10). The SHGB levels were significantly higher in the RYGB group.

The mean $\mathrm{AUC}_{(0-24 \mathrm{~h})}$ did not significantly differ between the groups $(\mathrm{p}=0.302)$ $(19.9 \pm 7.1 \mathrm{ng} * \mathrm{~h} / \mathrm{ml}$ in the operated group vs $17.0 \pm 8.1 \mathrm{ng} * \mathrm{~h} / \mathrm{ml}$ in the control group) (Figure 7).

The mean through value $\left(\mathrm{C}_{24 h}\right)$ did not significantly differ between the groups (Table 10).

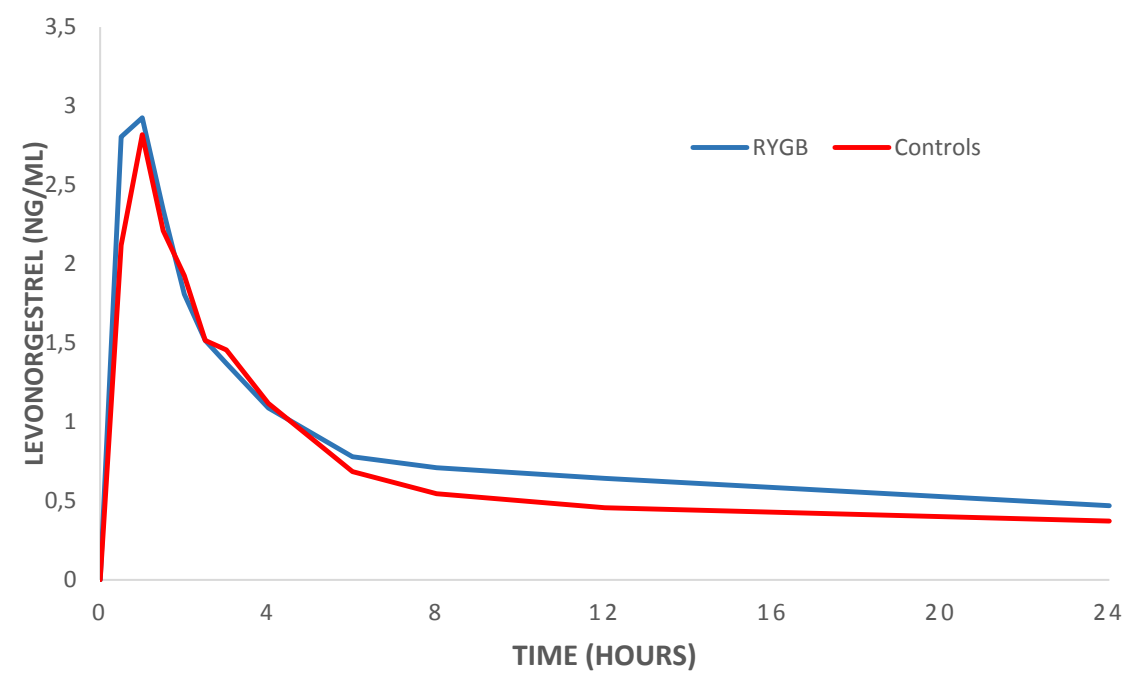

Figure 7. Mean values for the time course of levonorgestrel plasma concentration from 0-24 hours $\left(\mathrm{AUC}_{0-24}\right)$ for the 15 patients with a history of previous Roux-en-Y gastric bypass (RYGB) surgery and the 15 BMI-matched controls. 


\begin{tabular}{|c|c|c|c|}
\hline & Previous RYGB $(n=15)$ & $\begin{array}{l}\text { Controls } \\
(n=15)\end{array}$ & p-value \\
\hline \multicolumn{4}{|l|}{ Age (years) } \\
\hline Median (range) & $32(23-40)$ & $26(21-40)$ & \multirow[b]{2}{*}{$p=0.069$} \\
\hline Mean \pm SD & $32.3 \pm 5.2$ & $28.2 \pm 6.5$ & \\
\hline \multicolumn{4}{|l|}{ BMI $\left(\mathrm{kg} / \mathrm{m}^{2}\right)$} \\
\hline Mean \pm SD & $25.6 \pm 2.5$ & $25.1 \pm 3.1$ & \multirow{2}{*}{$p=0.619$} \\
\hline Min-max & $22.2-29.1$ & $19.5-29.4$ & \\
\hline \multicolumn{4}{|l|}{ Weight (kg) } \\
\hline Mean \pm SD & $70.8 \pm 8.2$ & $71.3 \pm 9.1$ & \multirow{2}{*}{$p=0.871$} \\
\hline Min-Max & $56.4-84.5$ & $56.3-85.1$ & \\
\hline \multicolumn{4}{|l|}{$\operatorname{AUC}_{0-24 h}\left(\mathrm{ng}^{*} \mathrm{~h} / \mathrm{ml}\right)$} \\
\hline Mean \pm SD & $19.9 \pm 7.1$ & $17.0 \pm 8.1$ & \multirow{2}{*}{$p=0.302$} \\
\hline Min-max & $10.7-30.6$ & $8.0-37.9$ & \\
\hline \multicolumn{4}{|l|}{$\overline{A U C_{0 \rightarrow \infty}}$} \\
\hline Mean \pm SD & $40.3 \pm 19.1$ & $29.6 \pm 14.3$ & \multirow[t]{2}{*}{$p=0.091$} \\
\hline Min-max & $20.4-81.0$ & $11.3-60.5$ & \\
\hline \multicolumn{4}{|l|}{$\mathrm{C}_{\max }(\mathrm{ng} / \mathrm{ml})$} \\
\hline Mean \pm SD & $3.34 \pm 1.16$ & $2.96 \pm 1.17$ & \multirow{2}{*}{$p=0.386$} \\
\hline Min-max & $1.56-5.25$ & $1.47-5.44$ & \\
\hline \multicolumn{4}{|l|}{$\mathrm{C}_{24 \mathrm{~h}}(\mathrm{ng} / \mathrm{ml})$} \\
\hline Mean \pm SD & $0.47 \pm 0.2$ & $0.37 \pm 0.2$ & \multirow{2}{*}{$p=0.181$} \\
\hline Min-Max & $0.23-0.85$ & $0.14-0.77$ & \\
\hline \multicolumn{4}{|l|}{$\mathbf{T}_{\max }(\mathbf{h})$} \\
\hline Median & 1 & 1 & \multirow[b]{3}{*}{$p=0.153$} \\
\hline Range & $(0.5-1.5)$ & $(0.5-2)$ & \\
\hline Mean \pm SD & $0.8 \pm 0.3$ & $1 \pm 0.4$ & \\
\hline \multicolumn{4}{|l|}{$t_{1 / 2}$ (hours) } \\
\hline Mean \pm SD & $29.1 \pm 14.6$ & $24.0 \pm 6.1$ & $p=0.223$ \\
\hline \multicolumn{4}{|l|}{$\mathrm{CL}_{\text {oral }}(\mathrm{L} / \mathrm{h})$} \\
\hline Mean \pm SD & $8.5 \pm 3.1$ & $10.5 \pm 4.3$ & $p=0.157$ \\
\hline \multicolumn{4}{|l|}{ SHBG (ng/ml) } \\
\hline Mean \pm SD & $87.5 \pm 24.6$ & $62.7 \pm 22.7$ & $p=0.008$ \\
\hline Min- max & $47.7-141.4$ & $27.3-111.4$ & \\
\hline
\end{tabular}

Table 10. Demographic and clinical characteristics and pharmacokinetic parameters of levonorgestrel in 15 patients and 15 controls.

$\mathrm{AUC}_{0-24 \mathrm{~h}}=$ area under the serum concentration time curves from 0 to 24 hours, $\mathrm{AUC}_{0 \rightarrow \infty}$

$=$ area under the serum concentration time curves from 0 to infinity, $\mathrm{C}_{\max }=$ peak serum concentrations, $\mathrm{C}_{24 \mathrm{~h}}=$ serum concentration $24 \mathrm{~h}$ after ingesting dose of levonorgestrel, $\mathrm{T}_{\max }=$ time to peak serum concentrations, $\mathrm{t}_{1 / 2}=$ terminal half-lives of levonorgestrel, $\mathrm{CL}_{\text {oral }}=$ apparent oral clearance of levonorgestrel, SHBG = sex hormone-binding globulin Independent $\mathrm{t}$-test was used for all statistical analyses. 
The intra-individual differences in $\mathrm{AUC}_{0-24}$ are graphically presented in figure 8 .

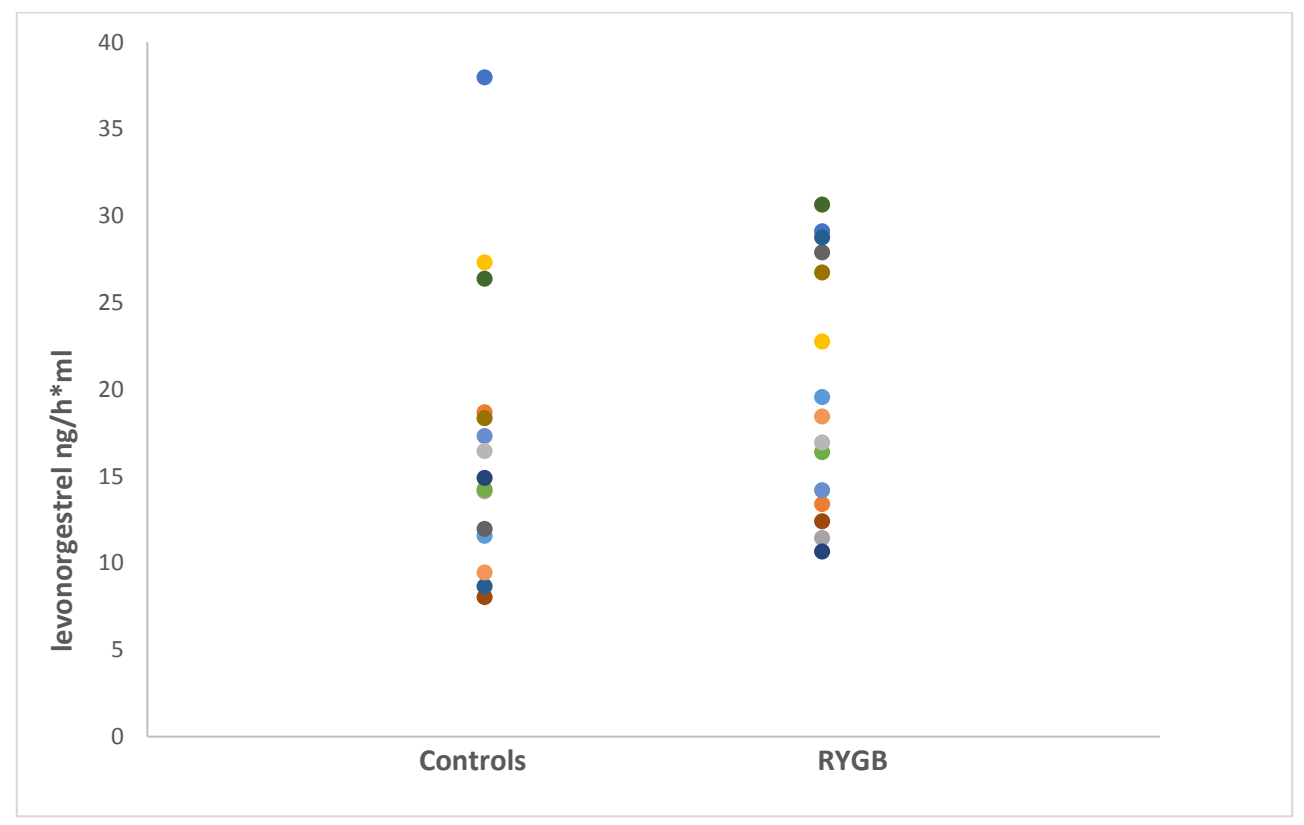

Figure 8. Individual values for the time course of levonorgestrel plasma concentration from 0-24 hours $\left(\mathrm{AUC}_{0-24}\right)$ for the 15 control patients. 


\section{Discussion}

\section{Methodological considerations}

\section{Retrospective cohort study versus cross-sectional questionnaire-based study}

Paper I is a retrospective cohort study and paper II is a cross-sectional questionnaire-based study. The retrospective cohort design can also be described as a historical cohort study with prospective assessment of outcome in relation to exposure. The term 'cohort' refers to a group of individuals from a defined population followed over time. The cohort design allows the evaluation of the association between an exposure and a specific outcome (120). Questionnaires are widely used in the collection of data in epidemiological studies. They allow information to be collected from large, geographically dispersed populations.

The validity, i.e. the degree to which the results of a study are correct for the specific study patients included, can be affected by systematic errors (bias) and random errors (chance). The risk of random errors is reduced by a large sample size (120).

The validity of a questionnaire reflects that the questions measures what you intend to measure. The questions in a questionnaire need to be constructed so that they are interpreted and understood in the way the investigators intended i.e. are valid. The questions also need to be constructed in such a way that they would give the same answer if repeated, i.e. the questionnaire should have a high reliability. The construction of the questions can be validated in terms of content and face validity. We used a cognitive interviewing technique (114) to perform an internal validation of our questionnaire of paper II, which led to the rephrasing of some questions. This gave the questionnaire a higher reliability and tested the face validity, i.e. how relevant the questionnaire appears to the study subjects in relation to what the study is supposed to measure (121).

To strengthen the validity of paper I we aimed to reduce selection bias (a type of systematic error) while including all women with obesity within a specific time frame in order to include a whole population. BMI is an exposure that is easy to define and therefore the selection bias is not affected by difficulties in defining study objects. However, our population is limited to the county of Östergötland and this is a type of selection bias that can affect the generalizability of the results nation- or world-wide. However, this county includes both urban and rural populations, i.e. both "white- and blue-collar" populations (122); thus we consider the population to most likely be representative and consequently the results valid for Swedish circumstances. 
A major disadvantage when using previously collected data in medical records is that the information on exposures and outcomes is limited to the information that is available in the medical records. The medical records used in paper I have not been adjusted to contain all the information needed to conduct our study but reflect information gathered and documented during everyday health care circumstances.

Information/misclassification bias occurs if information is recorded or measured inaccurately (120). One example of misclassification bias in paper I could be that different body weight scales were used at the different family planning units. Regular calibration of measurement instruments can reduce this kind of bias. However, the body weight must be incorrect by several kilograms to affect the BMI classification. The BMI could also be misclassified if the weight was self-reported, and with the structure of gathering information from medical records we cannot guarantee that all women were weighed on a weight scale. When scrutinising the patient records we found obvious registration errors leading to false high BMI and we therefore decided not to include women with a BMI above 50 because of the risk of uncertain data.

A possible misclassification in paper II could be due to time-recall bias. We asked questions regarding contraceptive use before and up to one year after surgery. There was a risk that the participants would not remember the exact time point at which they were using a specific contraceptive. To minimise the risk of not correctly remembering the answers to pre-surgery-related questions we included women who had undergone surgery recently and during the same year (2010). This was achieved through the help of SOReg which is a validated register with a high national coverage, enabling a population-based sample of participants. We also compared the data from SOReg to the answers in the questionnaire regarding preoperative BMI and this showed a good correlation, strengthening the reliability of the answers.

The retrospective design of paper I is associated with registration bias due to the frequent lack of information in the medical records. However, we had the same degree of lack of information in both groups of women, for example regarding reported bleeding pattern and reasons for discontinuation of contraceptive use. However, we cannot exclude the possibility that the lack of data has affected the results.

Non-response to questionnaires reduces the effective sample size and can introduce selection bias. A short questionnaire will increase the odds for a high response rate (123). When response rates are high, the potential for differences between respondents and non-respondents is lower, increasing the likelihood that survey results can be generalised to the population, and reducing the likelihood of response bias (124). The electronic questionnaire has become more common, and has shown higher response rates (125), but this was not an option 
for our study since we did not have access to electronic mail addresses to our population. We included a stamped return envelope and sent two reminders to non-responders in order to optimise response rates.

The validity of a cohort study can also be affected by structural problems regarding the extraction of information from the medical records and the following registration as study data. The inter-rater reliability will be affected if different researchers interpret information differently. There might also be a problem of intra-rater reliability if the same researcher interprets and records the same information differently at two different time points (126). In paper I, two researchers together collected all the information, and transferred it into research data, reducing the problem of inter-rater reliability.

We consider that the largest methodological drawback of study I (paper I) is the frequent lack of information in the medical records. However, we found no other available way to conduct a study like this, with such a large sample size. A prospectively performed study would be an alternative, but would be considerably more time-consuming to perform. Perhaps a national register regarding contraception would facilitate these types of studies, but such a register does not yet exist.

In paper II we aimed for a higher response rate than $57 \%$. A low response makes it hard to draw conclusions and generalise the results. It must be kept in mind when interpreting the results that a selection bias can be found among the responders and non-responders. We performed a drop out analysis to evaluate potential selection bias. We used prospectively collected data from SOReg to compare the group of responders to the non-responders. The groups were equal when comparing preoperative BMI, age and comorbidities such as hypertension and diabetes mellitus. The non-responders were significantly more often smokers. Perhaps this could indicate that the responders belong to a socioeconomically selected group. The total material might contain an even higher rate of women that have not been aware of, for example, the recommendations to avoid pregnancy postoperatively or recommendations not to use oral contraceptives. Lindh et al. have reported a change towards lower contraceptive use in low socioeconomic settings (127). The low response rate is the largest drawback of study II (paper II). 


\section{Pharmacokinetic studies}

Papers III and IV are experimental studies with a similar design. The fact that the study participants were their own controls (paper III) reduced the sample size required for the same statistical power in the same way as for a cross-over designed study (128).

We experienced difficulties particularly when including patients for paper III. The number of eligible patients was lower than anticipated. This was due to the steady state design, since there were fewer women using DSG preoperatively than we had anticipated. The eligible women also had to agree to continue use of DSG during the whole study period (approximately 15 months) and to agree to participate in three 24-h long blood sampling periods, which led to absence from work and loss of income. This complicated and prolonged the inclusion period of the study. These factors also contributed to the exclusion of at least one of the participants.

With the experience of the inclusion difficulties of study III (paper III) and to facilitate the inclusion for study IV (paper IV) we decided to plan for a multicentre study. For the same reason we also wanted to make study IV (paper IV) a single dose study, so we looked for women without hormonal contraception.

The drop out of the participants in study III (paper III) was higher than expected, in total five women.

The inclusion process of study IV (paper IV) was easier than for study III (paper III) and was performed without drop-outs so we consider the design better from this perspective. On the other hand, the studies reflect different objectives, such as intra- and inter-individual differences as well as single dose and steady state perspectives.

For both studies III and IV (paper III and IV) we chose to study the pharmacokinetics one year after surgery in order to perform analysis after the most rapid weight reduction. In study III (paper III) however, we also included sampling three months post-surgery in order to reveal any differences in close relation to surgery. The rationale for this was to investigate the pharmacokinetics during the period when the women are recommended not to become pregnant.

For both studies we had an ethnically homogenous group of women, which gives reliability to the results since pharmacokinetic mechanisms such as metabolism and protein binding can differ among ethnic groups (129). However, the ethnic homogeneity of the studies may hamper generalizability.

For study III and IV (paper III and IV) we had to set up the analytical method of UPLC/MS-MS to be able to perform the analyses. For practical and economic 
reasons EE was not measured in study IV (paper IV). This was mainly because the analysis of EE is not possible at the hospital laboratories of Sweden and we would have needed to set up this method as well. We considered it sufficient to measure the progestin of COC as it is this component, and not the oestrogen, that induces inhibition of ovulation.

The accuracy of the method tells us how much the measures vary when compared to standard solution of the measured substance. For study III (paper III) the accuracy varied between 94 and 104\% and for study IV (paper IV) between 86 and $89 \%$. Another validity test for the method is the intra-assay coefficients of variation, i.e. how one measurement of a sample differs from a second measurement of the same sample. The intra-assay coefficients of variation for paper III was between 6 and $11 \%$ and for study IV (paper IV) it was between 5 and $6 \%$. These quality-controls strengthen the validity of our results. The results are in accordance with previous pharmacokinetic studies of the same progestins $(56,118)$.

\section{Generalizability of the pharmacokinetic studies}

The results from studies III and IV (paper III and IV) may have an impact on contraceptive counselling for women around the world where RYGB is performed. The studies are not adjusted for ethnic pharmacokinetic differences, but as the women in study III (paper III) served as their own controls, we consider this of minor importance.

Since our studies were planned the choice of surgical method in bariatric surgery has begun to switch from RYGB towards sleeve gastrectomy. Sleeve gastrectomy could theoretically affect the absorption of drugs to a lesser extent than RYGB because the intestines are not bypassed. Recent studies comparing the pharmacokinetics of caffeine, paracetamol and rivaroxaban showed equal pharmacokinetic patterns for both surgical methods after surgery comparing with before surgery $(130,131)$. This makes it less likely that a pharmacokinetic study of the same progestins after sleeve gastrectomy would yield a different outcome compared with the result from the present studies (papers III and IV), but we propose further studies before making these assumptions. Studies III and IV (papers III and IV) were performed with a contraceptive perspective; however, our results are interesting also for women needing hormone replacement therapy (HRT) later in life. The results are only generalisable to the progestins of HRT containing desogestrel or levonorgestrel.

Our studies have focused on the pharmacokinetics of contraceptive progestins after RYGB, and no clinically relevant differences were found. It seems reasonable to believe that the contraceptive efficacy after RYGB is unchanged. Ideally, a pharmacokinetic study like ours should also study the risk of 
unintended pregnancies. However, to investigate the correlation between pharmacokinetic changes and actual risk of unintended pregnancies in women before compared with after bariatric surgery seems impossible from a practical point of view due to the need for a huge sample size.

\section{Methodological difficulties along the path as a PhD student}

As progestins have been presumed to be absorbed predominately in the upper gastrointestinal tract $(45,46)$, but have also been shown to be absorbed in the colon (47), we wanted to investigate a possible in vitro uptake of progestins in the jejunum.

A study was planned to examine the intestinal mucosa of the jejunum from small biopsies at the position of the distal part of the biliary limb in the RYGB construction. The Ussing chamber provides a method for measurement of electrolyte, nutrient and drug transport across epithelial tissues (132). We performed the experiment with jejunal tissues from four female patients of fertile age undergoing RYGB at Vrinnevisjukhuset in Norrköping. Aliqouts were drawn a 30, 60, 90 and 120 min for determination of LNG and DSG from the serosal part of the Ussing chamber after adding the substances in the mucosal part of the Ussing chamber. In order to analyse intestinal metabolism, aliquots were drawn to analyse ENG as well as LNG and DSG. Unfortunately, no substances were identifiable when running the UPLC/MS-MS. This was probably due to the in vitro situation with no blood circulation in the tissue. The substances were probably too lipophilic, which made them stick to the tissue and therefore they did not permeate the mucosal membrane. We could therefore not draw any conclusions regarding the presence or the lack of absorption of levonorgestrel and desogestrel in the jejunum.

In order to strengthen the possible clinical implication of study III (paper III) we considered performing another study in patients using desogestrel $75 \mu \mathrm{g}$ and evaluating signs of ovulation and changes in bleeding pattern. We wanted to include women of fertile ages and to ask them to fill out a menstrual pattern diary and to undergo regular ovarian ultrasound examination two times a month before RYGB, and three months and 12 months after RYGB. While planning the study, we realised that there would be great difficulty in recruiting patients and the project was never started. 


\section{Discussion and interpretation of the findings}

\section{Contraceptive prescription, use, reported side effects and discontinuation (paper I-II)}

We investigated the pattern of contraceptive use in two different cohorts of women with obesity. The majority of women had a BMI between 30 and 35 but 107 women had a BMI>35 kg/m² (paper I).

The most commonly contraceptive method prescribed to women with obesity was POP with a prescription rate of $44 \%$ (paper I). However, in the population that had undergone RYGB (paper II), the most commonly used method among women with obesity before RYGB surgery was the LNG-IUS (15.3\%). It must be kept in mind that although both populations consisted of women with obesity, the BMI in the women planned to undergo RYGB (paper II) was considerably higher ( 43.6 vs. $33 \mathrm{~kg} / \mathrm{m}^{2}$ ). The differences in the pattern of contraceptive use between these different populations with obesity might also be explained by other differences between the populations regarding parity ( 0 vs. 2$)$, and age (29 vs. 36 years). This is in accordance with the results from previous studies where use of intrauterine contraception has been shown to be more common among parous women compared to nulliparous women with obesity class II-III (133).

The hypothesis that POP was the most commonly used oral contraceptive method among women with obesity was confirmed. Forty-four percent (paper I) and $15.5 \%$ (paper II) used POP. When sub-analysing the women with obesity class II-III of paper I, the frequency of POP use was even higher $(56.1 \%)$.

The studies also revealed a surprisingly high prescription of $\mathrm{CHC}$ to women with obesity (papers I and II), despite the clinical recommendations to avoid oestrogen-containing contraception for women with obesity $(31,72,134)$.

The use of $\mathrm{CHC}$ was also much more common for the women with obesity class III of study II (paper II) compared with the women with obesity class II-III of study I (paper I). These differences may partly be explained by a recall bias in the group of women in study II (paper II). For some women, up to three years had passed since their surgery and it might have been hard to recall what type of oral contraceptive they had been using in the time before surgery. The difference might also be explained by local differences in prescription habits. Study I (paper I) reflects the county of Östergötland, while study II (paper II) is a nationwide survey. The number of included women using LARC was low (paper I). The inclusion period was one year (2010) and thus the users who had an IUD/LNGIUS or an implant inserted before the study period, the prevalent users, were missing since they did not show up for regular visits and did not need an annual prescription (paper I). We can assume that the actual number of LARC users in the population is substantially higher. 
In 2014, the national recommendations were updated and have changed towards a slightly more liberal point of view regarding $\mathrm{CHC}$ use for women with obesity class I. If a woman with a BMI 30-35 is a prevalent user, and if no other risk factors for VTE are present (31), she might continue CHC use. Both papers I and II reflect contraceptive use during the period before this change of recommendations.

POPs are the first oral contraceptive choice for women with obesity. However, POP use is associated with a higher degree of discontinuation due to side effects such as bleeding disturbances $(38,135)$. Irrespective of BMI, POP users discontinued their contraceptive method more often than CHC users (paper I), which is in accordance with the results from previous studies (27). POP users in general reported more bleeding disturbances compared with $\mathrm{CHC}$ users (paper I), which is in line with previous findings $(34,135)$. Women with obesity using POPs did not show an increased risk of an irregular bleeding pattern compared with normal-weight women using POPs. This is in line with the findings of Westhoff et al. who found no significant differences in bleeding/spotting episodes among obese women compared with normal-weight women using COCs (57).

Interestingly, however, women with obesity, regardless of method, were more prone to discontinue due to reported bleeding disturbances (paper I). The reason for this finding is unclear. It has previously been shown that women with obesity may have lower socioeconomic status than normal-weight women (127). It might be speculated that this might lead to increased vulnerability which is reflected here in a higher discontinuation rate. As expected, the prevalent users were more likely to adhere to their method than the incident users.

It should be kept in mind that the reasons for discontinuation were not mentioned in the records by almost half of the women, and bleeding problems might have been under-reported. However, there was no difference in lack of information between the groups and we do not believe that this factor biased the comparisons between the groups. The frequency of discontinuation was similar among women with obesity and normal-weight women, regardless of contraceptive method, indicating that the frequency of side effects in general does not differ among women in different BMI categories (paper I).

When choosing a contraceptive method for women with obesity, several factors must be considered; the acceptance and the prospect of continuation of the method by the patient, the safety profile, the efficacy and tolerability of the method and the thromboembolic and cardiovascular risk of the woman. Longacting reversible contraceptive methods offer long-term contraception without the increased risk of vascular adverse events associated with oestrogen. LNGIUS was the most commonly reported method among women both before and 
after RYGB (paper II). Women using LARC are more prone to continue their contraceptive method than women using short-acting contraceptive methods (28). Moreover, LNG-IUS are safe, well-tolerated and offer endometrial protection (136).

\section{Contraceptive counselling in relation to RYGB (paper II)}

A substantial number of the women who had undergone RYGB women $(39.6 \%)$ stated that they had received no or insufficient advice to avoid pregnancy for at least one year after surgery. Almost one fifth stated that they received no or insufficient contraceptive counselling in relation to surgery. At the same time, $30 \%$ did not use any contraception in the first 12 months following surgery. This may, at least in part, be explained by a pregnancy wish due to the obesity-related infertility that women with obesity may suffer from. However, the number is almost twice as high as previously reported by Mody et al. (137) and may therefore also reflect a lack of, or insufficient information but it may also reflect a recall bias.

These findings may imply that suboptimal contraceptive counselling was given to women undergoing RYGB surgery. A written national recommendation available online, or handed out to all women of fertile ages at the time of planning of the surgery could improve the counselling and increase the possibility of retention of the given information.

\section{Pharmacokinetics of ENG and LNG after RYGB (papers III and IV)}

AUC reflects the total exposure of the drug. The AUC of ENG did not significantly change after compared with before RYGB surgery. $\mathrm{C}_{\max }$ was the only pharmacokinetic parameter that showed a significant difference after compared with before surgery (paper III). However, a rise in peak serum concentration is not of major clinical interest. The through value $\left(\mathrm{C}_{24 \mathrm{~h}}\right)$ is more interesting as it reveals the lowest serum concentration over 24 hours. Previous studies of an ENG-releasing implant have shown that ovulation was inhibited with serum concentration levels $>90 \mathrm{pg} / \mathrm{ml}(51)$. The mean $\mathrm{C}_{(24 \mathrm{~h})}$ values of ENG were well above this level at all times in the study. The other pharmacokinetic parameters, including AUC, were in agreement with previously reported ENG pharmacokinetic parameters found in women of normal-weight (49). There were intra-individual differences in AUC before vs after RYGB (Figure 5) but all study participants had AUC values that always lay within previously described normal ranges (49). When comparing with other pharmacokinetic studies, Pena et al. had an even wider AUC range for ENG (1.19-23.5 $\mathrm{ng} * \mathrm{~h} / \mathrm{ml})$ in a study of 33 healthy women (49).

Our results in paper III suggest that the pharmacokinetics of DSG/ENG are not significantly affected by RYGB. 
Non-obese RYGB-operated women did not show any clinically relevant difference in the pharmacokinetic profile of LNG compared to BMI-matched non-operated women (paper IV). The intra-individual variations were similar in both groups and these variations were larger than the variations between the groups. The levels of $\mathrm{C}_{\max }$ were in line with previously described pharmacokinetics of LNG $(42,43)$. Our results of $\operatorname{AUC}_{(0-\infty)}$ showed lower values than the result of these previous studies; $(40.3 \pm 19 \mathrm{ng} * \mathrm{~h} / \mathrm{ml})$ vs $(47.3 \pm$ $15.5 \mathrm{ng} * \mathrm{~h} / \mathrm{ml})$ and $(51.7 \pm 22 \mathrm{ng} * \mathrm{~h} / \mathrm{ml})$. However, we consider it more likely that these differences were related to methodological differences (analytical) than to an actual difference $(42,43)$.

Consequently, the results could not confirm our hypothesis, and RYGB does not seem to have any major effect on the pharmacokinetics of LNG in women with a $\mathrm{BMI}<30$. A previous seven-year study of LNG implants showed that, regardless of body weight, women with LNG levels above $0.3 \mathrm{ng} / \mathrm{ml}$ did not become pregnant (44). We present mean through values that reached this level even after a single oral dose.

Papers III and IV are unique; they are to our knowledge the first pharmacokinetic studies of progestins in relation to RYGB. They provide important knowledge in this field that will contribute to future improvement of contraceptive counselling to women after RYGB. 


\section{Conclusions}

- The most commonly prescribed contraceptive method for women with obesity was POP (paper I).

- A significant number of women with obesity were prescribed (paper I) or reported use of (paper II) CHC.

- Women with obesity showed the same pattern as normal-weight women regarding the number of used/prescribed contraceptive methods and the number of contacts with family planning units (paper I).

- From a nationwide perspective, long-acting reversible contraceptive methods, such as LNG-IUS, IUDs and implants were more common than oral contraceptives in women with obesity class III scheduled for RYGB surgery (paper II).

- Many women continue using oral contraceptives despite the current recommendations to avoid oral methods after RYGB (paper II).

- Almost one third of RYGB operated women reported no use of any contraceptive method at all in the first 12 months after surgery and even more women reported being unaware of the recommendations to avoid pregnancy during this period (paper II).

- RYGB does not seem to affect the pharmacokinetics of oral DSG(ENG) from a clinically-relevant perspective (paper III).

- The pharmacokinetics of oral LNG in women with $\mathrm{BMI}<30$ after having undergone RYGB do not differ from the LNG pharmacokinetics in BMImatched non-operated women (paper $I V$ ). 


\section{Future perspectives}

To be able to offer women with obesity the same quality of contraceptive counselling as normal-weight women, increased focus needs to be directed towards research on the contraception prescribed to this growing group of women.

The family planning units present an excellent opportunity to discuss weight management at the time contraceptive counselling. Weight management could also be discussed in relation to future pregnancy wishes, i.e. in relation to reproductive life plan (138). Future research needs to focus on investigating the acceptability of this type of discussion and how to best address the topic.

The question of contraceptive efficacy in women with obesity has started to attract attention in recent years. There are still gaps in the knowledge concerning discontinuation rates and frequency of side effects of different contraceptive methods in women with obesity compared to normal-weight women. Registers of contraception and abortion could provide a way to gain access to information and to perform large cohort studies in the field. But since these registers do not exist in Sweden, we presently need to rely on information from medical records or questionnaires.

A prospective questionnaire study concerning contraceptive use before and after gastric bypass, adherence to recommendations regarding avoidance of pregnancy etc. could be performed using repeated questionnaires at the surgical clinic before bariatric surgery and at the visits after surgery. With the present distribution of bariatric surgery, this would, cover women undergoing both RYGB and sleeve gastrectomy.

The pharmacokinetics of desogestrel and levonorgestrel do not seem to be affected by RYGB surgery, but we cannot with certainty draw any conclusions regarding the pharmacokinetics of other progestins. Further studies are needed. It would also be interesting to investigate the pharmacokinetics of LNG in women who have undergone sleeve gastrectomy. Theoretically this procedure would be less likely to interfere with the pharmacokinetics of progestins than RYGB, but this has yet to be examined.

Studies concerning pharmacokinetics after RYGB and sleeve gastrectomy of drugs commonly used in HRT are also of interest for the large group of women that have undergone or will undergo bariatric surgery.

The field of medical termination of pregnancy after RYGB surgery is yet to be investigated. Pharmacokinetic investigation of mifepristone in relation to 
bariatric surgery could be a way to examine the possible effect of RYGB on these drugs. 


\section{Populärvetenskaplig sammanfattning}

\section{Preventivmedel till kvinnor med fetma och fetmakirurgins påverkan på preventivmedel}

Fetma är ett växande globalt folkhälsoproblem. Antalet vuxna med fetma uppgick 2016 till fler än 650 millioner världen över, motsvarande $13 \%$ av världens befolkning. I Sverige har $16 \%$ av den vuxna befolkningen fetma med $\mathrm{BMI}>30 \mathrm{~kg} / \mathrm{m}^{2}$, vilket är definitionen på fetma.

I Sverige utfördes 5400 operationer mot fetma 2017 och världen över utfördes 635000 operationer mot fetma 2016. Gastric bypass är fortfarande den mest använda kirurgiska metoden i Sverige. Fetmakirurgi leder till viktnedgång på ca $38 \mathrm{~kg}$ inom det första året och under denna tid rekommenderas den opererade kvinnan att inte bli gravid då en graviditet kan påverka viktnedgången negativt och dessutom möjligen kan ha en negativ inverkan på fostret. Detta innebär att det viktigt att den opererade kvinnan använder ett effektivt preventivmedel det första året efter operationen. Efter ca 12-18 månader stabiliseras vikten. Man vet inte säkert om fetmakirurgi påverkar upptaget och effektiviteten av hormonella preventivmedel.

Den aktuella doktorsavhandlingen beskriver preventivmedelsförskrivningen till kvinnor med fetma och jämför med förskrivningen till normalviktiga kvinnor. Resultaten visar bla att kvinnor med fetma i hög grad förskrivs medelhögt doserade p-piller med enbart gulkroppshormon, sk "mellanpiller", helt i linje med de nationella rekommendationerna.

Avhandlingen visar även att fyra av tio kvinnor som genomgår gastric bypass inte har uppfattat rekommendationen att undvika att bli gravid under 12-18 månader direkt efter operationen. Med anledning av ovan nämnda resultat kan den information som ges till kvinnor i barnafödande ålder i anslutning till fetmakirurgi behöva kartläggas närmare och kanske även samordnas över hela Sverige.

Efter gastric bypass kan upptaget av läkemedel påverkas. Vad som händer med upptaget av de läkemedel som finns i p-piller och mellanpiller är inte känt och i dagsläget avråds kvinnor från att använda dessa efter operationen och hänvisas till övriga preventivmedelsmetoder. Enligt en av avhandlingens studier använde nästan $10 \%$ av kvinnorna som genomgått operationen ändå dessa preventivmedel. 
I avhandlingsarbetet har de verksamma substanserna hos ett p-piller och ett mellanpiller undersökts i två läkemedelsstudier bland kvinnor som genomgått gastric bypass. Ingen av dessa studier kunde visa någon förändring i den verksamma substansens koncentration i blodet under mätningar i 24-timmar.

Liknande studier har tidigare inte utförts och resultaten talar för att de studerade p-pillrens effekt inte påverkas av fetmakirurgi och att de förmodligen kan användas efter fetmakirurgi när stabil vikt har uppnåtts. 


\section{Acknowledgements}

I would like to thank all of you who have encouraged and supported me during this $\mathrm{PhD}$ project.

In particular, I would like to thank the ones that have helped me reach my goal:

Professor Jan Brynhildsen, my main supervisor. You have supported me in many ways. From the very beginning you let me work independently and still I have always felt that you have been available at all times. Your trust in me has made me grow, and your good mood and constructive criticism is inspiring. You are always ready to share advice in a great mix from wine to parenting. Thank you!

Jessica Frisk, my co-supervisor for your never-ending enthusiasm and for being full of ideas of future projects. Your encouragement and your help in the recruitment process of study participants has been invaluable.

Ingela Jakobsson for your endless enthusiasm and help. You have taken such good care of all the study participants. Without you we would have had many more dropouts!

Professor Staffan Hägg and professor Ylva Böttiger for the most valuable help with two of the studies and for introducing me to the world of pharmacokinetics.

Helena Kopp Kallner and Jenny Silwer-Fagerberg for your help with the inclusion of many study participants and valuable constructive criticism.

Micaela Sundell for enthusiastic and always very cheerful partnership.

Mats Fredriksson for statistical help whenever needed.

Björn Carlsson and Andreas Ärlemalm for making the analysis of etonogestrel and levonorgestrel possible.

Pernilla Ekholm for your interest in my project. Your project has also been very valuable to me.

Patrik Lundqvist for all your help trying to make the Ussing experiment work.

Helene Fagraeus and Annelie Sjölund for taking such good care of the study participants. 
Anneli Villaume for the help with inclusion of study participants.

Both Lotta Lind Åstrand and Marika Wenemark for professional help with developing the questionnaire. Lotta was also most helpful with the first application to the Medical Products Agency, such patience you had with me!

Karin Skoglund, Lina Malm och Malin Huss from Forum Östergötland for impeccable monitoring of the pharmacokinetic studies.

Ingrid Forslund and Agnes Månsson for your thorough work with data registration.

Professor emeritus Mats Hammar, professor Marie Blomberg, Dr Gabriella Falk, professor Preben Kjölhede, Dr Michael Andresen and Dr Caroline Lilliecreutz for taking the time to review my thesis and manuscripts and contributing with valuable opinions.

Dr Ninnie Boerndal Wodlin, head of the Department of Obstetrics and Gynecology in Linköping, Dr Elizabeth Nedstrand, dr Annika Jeppsson and dr Kristina Kernell and dr Anna Ramö Isgren for giving me the time and schedule to complete this thesis.

The enthusiastic fellow PhD students that I have come to know during the years, thank you for interesting discussions and inspiration.

All women participating in the studies, thank you!

I am of course also very grateful to have so many dear friends and a wonderful family; my amazing husband Fredrik and our children Gustaf and Ottilia. 


\section{References}

1. Obesity: preventing and managing the global epidemic. Report of a WHO consultation. World Health Organ Tech Rep Ser. 2000;894:i-xii, 1-253.

2. Camhi SM, Bray GA, Bouchard C, Greenway FL, Johnson WD, Newton RL, et al. The relationship of waist circumference and $\mathrm{BMI}$ to visceral, subcutaneous, and total body fat: sex and race differences. Obesity. 2011;19(2):402-8.

3. Collaboration NCDRF. Trends in adult body-mass index in 200 countries from 1975 to 2014: a pooled analysis of 1698 population-based measurement studies with 19.2 million participants. Lancet. 2016;387(10026):1377-96.

4. World Health Organization. Obesity and overweight. Fact sheet; 2018. [Acessed 2019 April 7] https://www.who.int/en/news-room/fact-sheets/detail/obesity-and-overweight

5. NCHS C. https://www.cdc.gov/nchs/data/databriefs/db288.pdf 2017

6. $\quad$ Folkhälsomyndigheten. Så mår Sveriges befolkning; 2018. [Acessed 2019 April 7]. https://www.folkhalsomyndigheten.se/nyheter-och-press/nyhetsarkiv/2018/december/samar-sveriges-befolkning--ny-statistik-om-folkhalsan-2018/

7. McTigue K, Larson JC, Valoski A, Burke G, Kotchen J, Lewis CE, et al. Mortality and cardiac and vascular outcomes in extremely obese women. JAMA. 2006;296(1):79-86.

8. Meigs JB, Wilson PW, Fox CS, Vasan RS, Nathan DM, Sullivan LM, et al. Body mass index, metabolic syndrome, and risk of type 2 diabetes or cardiovascular disease. J Clin Endocrinol Metab. 2006;91(8):2906-12.

9. Cabrera MA, Gebara OC, Diament J, Nussbacher A, Rosano G, Wajngarten M. Metabolic syndrome, abdominal obesity, and cardiovascular risk in elderly women. Int J Cardiol. 2007;114(2):224-9.

10. Calle EE, Rodriguez C, Walker-Thurmond K, Thun MJ. Overweight, obesity, and mortality from cancer in a prospectively studied cohort of U.S. adults. N Engl J Med. 2003;348(17):1625-38.

11. Young T, Skatrud J, Peppard PE. Risk factors for obstructive sleep apnea in adults. JAMA. 2004;291(16):2013-6.

12. Dietrich $P$, Hellerbrand C. Non-alcoholic fatty liver disease, obesity and the metabolic syndrome. Best Pract Res Clin Gastroenterol. 2014;28(4):637-53.

13. Metwally M, Li TC, Ledger WL. The impact of obesity on female reproductive function. Obes Rev. 2007;8(6):515-23.

14. Practice Committee of the American Society for Reproductive M. Obesity and reproduction: a committee opinion. Fertility and sterility. 2015;104(5):1116-26.

15. Blomberg M. Maternal obesity and risk of postpartum hemorrhage. Obstet Gynecol. 2011;118(3):561-8.

16. Cedergren MI. Maternal morbid obesity and the risk of adverse pregnancy outcome. Obstet Gynecol. 2004;103(2):219-24.

17. Clark MAH, R.A.; Finkel R.; Rey, J.A.; Whalen, K. Pharmacology. : Lippincott Williams \& Wilkins; 2011.

18. Kuhl H. Pharmacology of estrogens and progestogens: influence of different routes of administration. Climacteric. 2005;8 Suppl 1:3-63.

19. Dhont M. History of oral contraception. The European journal of contraception \& reproductive health care : the official journal of the European Society of Contraception. 2010;15 Suppl 2:S12-8. 
20. Inman WH, Vessey MP, Westerholm B, Engelund A. Thromboembolic disease and the steroidal content of oral contraceptives. A report to the Committee on Safety of Drugs. $\mathrm{Br}$ Med J. 1970;2(5703):203-9.

21. Bottiger LE, Boman G, Eklund G, Westerholm B. Oral contraceptives and thromboembolic disease: effects of lowering oestrogen content. Lancet. 1980;1(8178):1097101.

22. Vessey MP, Doll R. Investigation of relation between use of oral contraceptives and thromboembolic disease. Br Med J. 1968;2(5599):199-205.

23. Lewis MA, Heinemann LA, Spitzer WO, MacRae KD, Bruppacher R. The use of oral contraceptives and the occurrence of acute myocardial infarction in young women. Results from the Transnational Study on Oral Contraceptives and the Health of Young Women. Contraception. 1997;56(3):129-40.

24. Leblanc ES, Laws A. Benefits and risks of third-generation oral contraceptives. J Gen Intern Med. 1999;14(10):625-32.

25. Fritz MA, Speroff, L. Oral Contraception. In: Fritz MA and Speroff L. Clinical gynecologic endocrinology and infertility. : Philadelphia PA, Lippincott Williams \& Wikins; 2011.

26. Sitruk-Ware R. Pharmacological profile of progestins. Maturitas. 2008;61(1-2):151-7. 27. Josefsson A, Wirehn AB, Lindberg M, Foldemo A, Brynhildsen J. Continuation rates of oral hormonal contraceptives in a cohort of first-time users: a population-based registry study, Sweden 2005-2010. BMJ Open. 2013;3(10):e003401.

28. Trussell J. Contraceptive failure in the United States. Contraception. 2011;83(5):397404.

29. Lindh I, Skjeldestad FE, Gemzell-Danielsson K, Heikinheimo O, Hognert H, Milsom I, et al. Contraceptive use in the Nordic countries. Acta Obstet Gynecol Scand. 2017;96(1):19-28.

30. Odlind V BM, Milson I. Familjeplanering:preventivmetoder, aborter och rådgivning. 1 ed. Lund: Studentlitteratur AB; 2008.

31. Läkemedelsverket. Antikonception-behandlingsrekommendation. Information från läkemedelsverket. 2014;25(2):14-28. In Swedish. 2014.

32. Hall KS, Trussell J, Schwarz EB. Progestin-only contraceptive pill use among women in the United States. Contraception. 2012;86(6):653-8.

33. Moghissi KS, Marks C. Effects of microdose norgestrel on endogenous gonadotropic and steroid hormones, cervical mucus properties, vaginal cytology, and endometrium. Fertility and sterility. 1971;22(7):424-34.

34. McCann MF, Potter LS. Progestin-only oral contraception: a comprehensive review. Contraception. 1994;50(6 Suppl 1):S1-195.

35. Rice $\mathrm{C}$, Killick S, Hickling D, Coelingh Bennink H. Ovarian activity and vaginal bleeding patterns with a desogestrel-only preparation at three different doses. Human reproduction. 1996;11(4):737-40.

36. Rice CF, Killick SR, Dieben T, Coelingh Bennink H. A comparison of the inhibition of ovulation achieved by desogestrel 75 micrograms and levonorgestrel 30 micrograms daily. Human reproduction. 1999;14(4):982-5.

37. Korver T, Klipping C, Heger-Mahn D, Duijkers I, van Osta G, Dieben T. Maintenance of ovulation inhibition with the 75-microg desogestrel-only contraceptive pill (Cerazette) after scheduled 12-h delays in tablet intake. Contraception. 2005;71(1):8-13. 
38. Korver T. A double-blind study comparing thecontraceptive efficacy, acceptability and safety of two progestogen-only pills containing desogestrel $75 \mu \mathrm{g} /$ day or levonorgestrel $30 \mu \mathrm{g} /$ day: Collaborative Study Group on the Desogestrel-containing Progestogen-only Pill. The European Journal of Contraception and Reproductive Health Care. 1998;3:169-78.

39. Seo IH, Lee HB, Kim S, Lee YJ, Jung DH. Inverse Relationship between Hepatic Steatosis and Alanine Aminotransferase with Sex Hormone-Binding Globulin in Men. Yonsei Med J. 2017;58(4):731-6.

40. Flechtner-Mors M, Schick A, Oeztuerk S, Haenle MM, Wilhelm M, Koenig W, et al. Associations of fatty liver disease and other factors affecting serum SHBG concentrations: a population based study on 1657 subjects. Horm Metab Res. 2014;46(4):287-93.

41. FASS https://www.fass.se/LIF/product?userType=0\&nplld=19751105000034

42. Menon S, Riese R, Wang R, Alvey CW, Shi H, Petit W, et al. Evaluation of the Effect of Tofacitinib on the Pharmacokinetics of Oral Contraceptive Steroids in Healthy Female Volunteers. Clin Pharmacol Drug Dev. 2016;5(5):336-42.

43. Mohamed MF, Trueman S, Feng T, Friedman A, Othman AA. The JAK1 Inhibitor Upadacitinib Has No Effect on the Pharmacokinetics of Levonorgestrel and Ethinylestradiol: A Study in Healthy Female Subjects. J Clin Pharmacol. 2019;59(4):510-6.

44. Sivin I, Wan L, Ranta S, Alvarez F, Brache V, Mishell DR, Jr., et al. Levonorgestrel concentrations during 7 years of continuous use of Jadelle contraceptive implants. Contraception. 2001;64(1):43-9.

45. Nilsson LO, Victor A, Kral JG, Johansson ED, Kock NG. Absorption of an oral contraceptive gestagen in ulcerative colitis before and after proctocolectomy and construction of a continent ileostomy. Contraception. 1985;31(2):195-204.

46. Grimmer SF, Back DJ, Orme ML, Cowie A, Gilmore I, Tjia J. The bioavailability of ethinyloestradiol and levonorgestrel in patients with an ileostomy. Contraception. 1986;33(1):51-9.

47. Madden S, Back DJ, Martin CA, Orme ML. Metabolism of the contraceptive steroid desogestrel by the intestinal mucosa. British journal of clinical pharmacology. 1989;27(3):295-9.

48. Viinikka L, Ylikorkala O, Vihko R, Wijnand HP, Booij M, van der Veen F. Metabolism of a new synthetic progestagen, Org 2969, in female volunteers. Pharmacokinetics after an oral dose. European journal of clinical pharmacology. 1979;15(5):349-55.

49. Pena MA, Sanz E, Francisco S, Alonso A, Abajo Z, Felipe I, et al. Randomized, Crossover and Single-Dose Bioquivalence Study of Two Oral Desogestrel Formulations (FilmCoated Tablets of 75 mug) in Healthy Female Volunteers. Sci Pharm. 2012;80(2):419-31.

50. Grandi G, Cagnacci A, Volpe A. Pharmacokinetic evaluation of desogestrel as a female contraceptive. Expert opinion on drug metabolism \& toxicology. 2014;10(1):1-10.

51. Diaz S, Pavez M, Moo-Young AJ, Bardin CW, Croxatto HB. Clinical trial with 3-ketodesogestrel subdermal implants. Contraception. 1991;44(4):393-408.

52. Makarainen L, van Beek A, Tuomivaara L, Asplund B, Coelingh Bennink H. Ovarian function during the use of a single contraceptive implant: Implanon compared with Norplant. Fertility and sterility. 1998;69(4):714-21.

53. Simmons KB, Edelman AB. Hormonal contraception and obesity. Fertility and sterility. 2016;106(6):1282-8. 
54. Luo D, Westhoff CL, Edelman AB, Natavio M, Stanczyk FZ, Jusko WJ. Altered pharmacokinetics of combined Oral contraceptives in obesity - multi-study assessment. Contraception. 2019.

55. Natavio M, Stanczyk FZ, Molins EAG, Nelson A, Jusko WJ. Pharmacokinetics of the $1.5 \mathrm{mg}$ levonorgestrel emergency contraceptive in women with normal, obese and extremely obese body mass index. Contraception. 2019.

56. Westhoff CL, Torgal AH, Mayeda ER, Pike MC, Stanczyk FZ. Pharmacokinetics of a combined oral contraceptive in obese and normal-weight women. Contraception. 2010;81(6):474-80.

57. Westhoff CL, Torgal AH, Mayeda ER, Stanczyk FZ, Lerner JP, Benn EK, et al. Ovarian suppression in normal-weight and obese women during oral contraceptive use: a randomized controlled trial. Obstet Gynecol. 2010;116(2 Pt 1):275-83.

58. Edelman AB, Cherala G, Munar MY, Dubois B, McInnis M, Stanczyk FZ, et al. Prolonged monitoring of ethinyl estradiol and levonorgestrel levels confirms an altered pharmacokinetic profile in obese oral contraceptives users. Contraception. 2013;87(2):2206.

59. McNicholas C, Zhao Q, Secura G, Allsworth JE, Madden T, Peipert JF. Contraceptive failures in overweight and obese combined hormonal contraceptive users. Obstet Gynecol. 2013;121(3):585-92.

60. Lopez LM, Bernholc A, Chen M, Grey TW, Otterness C, Westhoff C, et al. Hormonal contraceptives for contraception in overweight or obese women. Cochrane Database Syst Rev. 2016(8):CD008452.

61. Edelman AB, Carlson NE, Cherala G, Munar MY, Stouffer RL, Cameron JL, et al. Impact of obesity on oral contraceptive pharmacokinetics and hypothalamic-pituitary-ovarian activity. Contraception. 2009;80(2):119-27.

62. Westhoff CL, Torgal AH, Mayeda ER, Petrie K, Thomas T, Dragoman M, et al. Pharmacokinetics and ovarian suppression during use of a contraceptive vaginal ring in normal-weight and obese women. Am J Obstet Gynecol. 2012;207(1):39 e1-6.

63. Vessey M. Oral contraceptive failures and body weight: findings in a large cohort study. J Fam Plann Reprod Health Care. 2001;27(2):90-1.

64. Abdollahi M, Cushman M, Rosendaal FR. Obesity: risk of venous thrombosis and the interaction with coagulation factor levels and oral contraceptive use. Thromb Haemost. 2003;89(3):493-8.

65. Pomp ER, le Cessie S, Rosendaal FR, Doggen CJ. Risk of venous thrombosis: obesity and its joint effect with oral contraceptive use and prothrombotic mutations. Br J Haematol. 2007;139(2):289-96.

66. Goldhaber SZ, Grodstein F, Stampfer MJ, Manson JE, Colditz GA, Speizer FE, et al. A prospective study of risk factors for pulmonary embolism in women. JAMA. 1997;277(8):642-5.

67. Rabe T LB, Ludwig M, Dinger JC, Bauersachs R, Rott $H$, Mueck AO, Albring CJ. Contraception and Thrombophilia - A statement from the German Society of Gynecological Endocrinology and Reproductive Medicine (DGGEF e. V.) and the Professional Association of the German Gynaecologists (BVF e. V.). Journal für Reproduktionsmedizin und Endokrinologie. 2011;8(1).

68. Lidegaard O, Edstrom B, Kreiner S. Oral contraceptives and venous thromboembolism: a five-year national case-control study. Contraception. 2002;65(3):18796. 
69. Wu CQ, Grandi SM, Filion KB, Abenhaim HA, Joseph L, Eisenberg MJ. Drospirenonecontaining oral contraceptive pills and the risk of venous and arterial thrombosis: a systematic review. BJOG : an international journal of obstetrics and gynaecology. 2013;120(7):801-10.

70. de Bastos M, Stegeman BH, Rosendaal FR, Van Hylckama Vlieg A, Helmerhorst FM, Stijnen T, et al. Combined oral contraceptives: venous thrombosis. Cochrane Database Syst Rev. 2014(3):CD010813.

71. Kemmeren JM, Algra A, Meijers JC, Tans G, Bouma BN, Curvers J, et al. Effect of second- and third-generation oral contraceptives on the protein $C$ system in the absence or presence of the factor VLeiden mutation: a randomized trial. Blood. 2004;103(3):927-33.

72. Merki-Feld GS, Skouby S, Serfaty D, Lech M, Bitzer J, Crosignani PG, et al. European society of contraception statement on contraception in obese women. The European journal of contraception \& reproductive health care : the official journal of the European Society of Contraception. 2015;20(1):19-28.

73. Colquitt JL, Pickett K, Loveman E, Frampton GK. Surgery for weight loss in adults. Cochrane Database Syst Rev. 2014(8):CD003641.

74. Sjostrom L. Review of the key results from the Swedish Obese Subjects (SOS) trial - a prospective controlled intervention study of bariatric surgery. J Intern Med. 2013;273(3):219-34.

75. SOReg. Annual report SOReg 2017. Scandinavian Obesity Surgery Registry 2017. (In Swedish). 2018 [

76. Angrisani L, Santonicola A, lovino P, Vitiello A, Higa K, Himpens J, et al. IFSO Worldwide Survey 2016: Primary, Endoluminal, and Revisional Procedures. Obes Surg. 2018;28(12):3783-94.

77. Merhi ZO. Impact of bariatric surgery on female reproduction. Fertility and sterility. 2009;92(5):1501-8.

78. Pucci A, Batterham RL. Mechanisms underlying the weight loss effects of RYGB and SG: similar, yet different. J Endocrinol Invest. 2019;42(2):117-28.

79. Batterham RL, Cowley MA, Small CJ, Herzog H, Cohen MA, Dakin CL, et al. Gut hormone PYY(3-36) physiologically inhibits food intake. Nature. 2002;418(6898):650-4. 80. Scott WR, Batterham RL. Roux-en-Y gastric bypass and laparoscopic sleeve gastrectomy: understanding weight loss and improvements in type 2 diabetes after bariatric surgery. Am J Physiol Regul Integr Comp Physiol. 2011;301(1):R15-27.

81. Muller TD, Nogueiras R, Andermann ML, Andrews ZB, Anker SD, Argente J, et al. Ghrelin. Mol Metab. 2015;4(6):437-60.

82. SOReg. Annual Report SOReg 2016. Scandinavian obesity surgery register 2016.

83. Carreau AM, Nadeau M, Marceau S, Marceau P, Weisnagel SJ. Pregnancy after Bariatric Surgery: Balancing Risks and Benefits. Can J Diabetes. 2017;41(4):432-8.

84. Welbourn R, Hollyman M, Kinsman R, Dixon J, Liem R, Ottosson J, et al. Bariatric Surgery Worldwide: Baseline Demographic Description and One-Year Outcomes from the Fourth IFSO Global Registry Report 2018. Obes Surg. 2018.

85. ACOG practice bulletin no. 105: bariatric surgery and pregnancy. Obstet Gynecol. 2009;113(6):1405-13. 
86. Mechanick JI, Youdim A, Jones DB, Garvey WT, Hurley DL, McMahon MM, et al. Clinical practice guidelines for the perioperative nutritional, metabolic, and nonsurgical support of the bariatric surgery patient--2013 update: cosponsored by American Association of Clinical Endocrinologists, the Obesity Society, and American Society for Metabolic \& Bariatric Surgery. Endocr Pract. 2013;19(2):337-72.

87. Roos N, Neovius M, Cnattingius S, Trolle Lagerros Y, Saaf M, Granath F, et al. Perinatal outcomes after bariatric surgery: nationwide population based matched cohort study. BMJ. 2013;347:f6460.

88. Willis K, Lieberman N, Sheiner E. Pregnancy and neonatal outcome after bariatric surgery. Best Pract Res Clin Obstet Gynaecol. 2015;29(1):133-44.

89. Kjaer MM, Lauenborg J, Breum BM, Nilas L. The risk of adverse pregnancy outcome after bariatric surgery: a nationwide register-based matched cohort study. Am J Obstet Gynecol. 2013;208(6):464 e1-5.

90. Galazis N, Docheva N, Simillis C, Nicolaides KH. Maternal and neonatal outcomes in women undergoing bariatric surgery: a systematic review and meta-analysis. Eur J Obstet Gynecol Reprod Biol. 2014;181:45-53.

91. Johansson K, Cnattingius S, Naslund I, Roos N, Trolle Lagerros Y, Granath F, et al. Outcomes of pregnancy after bariatric surgery. N Engl J Med. 2015;372(9):814-24.

92. Yau PO, Parikh M, Saunders JK, Chui P, Zablocki T, Welcome AU. Pregnancy after bariatric surgery: the effect of time-to-conception on pregnancy outcomes. Surgery for obesity and related diseases : official journal of the American Society for Bariatric Surgery. 2017;13(11):1899-905.

93. Sheiner E, Edri A, Balaban E, Levi I, Aricha-Tamir B. Pregnancy outcome of patients who conceive during or after the first year following bariatric surgery. Am J Obstet Gynecol. 2011;204(1):50 e1-6.

94. Parent B, Martopullo I, Weiss NS, Khandelwal S, Fay EE, Rowhani-Rahbar A. Bariatric Surgery in Women of Childbearing Age, Timing Between an Operation and Birth, and Associated Perinatal Complications. JAMA Surg. 2017;152(2):128-35.

95. Smith A, Henriksen B, Cohen A. Pharmacokinetic considerations in Roux-en-Y gastric bypass patients. Am J Health Syst Pharm. 2011;68(23):2241-7.

96. Mitra A, Kesisoglou F. Impaired drug absorption due to high stomach pH: a review of strategies for mitigation of such effect to enable pharmaceutical product development. Mol Pharm. 2013;10(11):3970-9.

97. Roerig JL, Steffen K, Zimmerman C, Mitchell JE, Crosby RD, Cao L. Preliminary comparison of sertraline levels in postbariatric surgery patients versus matched nonsurgical cohort. Surgery for obesity and related diseases : official journal of the American Society for Bariatric Surgery. 2012;8(1):62-6.

98. Roerig JL, Steffen KJ, Zimmerman C, Mitchell JE, Crosby RD, Cao L. A comparison of duloxetine plasma levels in postbariatric surgery patients versus matched nonsurgical control subjects. J Clin Psychopharmacol. 2013;33(4):479-84.

99. Marzinke MA, Petrides AK, Steele K, Schweitzer MA, Magnuson TH, Reinblatt SP, et al. Decreased Escitalopram Concentrations Post-Roux-en-Y Gastric Bypass Surgery. Ther Drug Monit. 2015;37(3):408-12.

100. Tandra S, Chalasani N, Jones DR, Mattar S, Hall SD, Vuppalanchi R. Pharmacokinetic and pharmacodynamic alterations in the Roux-en-Y gastric bypass recipients. Annals of surgery. 2013;258(2):262-9. 
101. Krieger CA, Cunningham JL, Reid JM, Langman LJ, Grothe KB, Clark MM, et al. Comparison of Bioavailability of Single-Dose Extended-Release Venlafaxine Capsules in Obese Patients Before and After Gastric Bypass Surgery. Pharmacotherapy. 2017.

102. Gesquiere I, Darwich AS, Van der Schueren B, de Hoon J, Lannoo M, Matthys C, et al. Drug disposition and modelling before and after gastric bypass: immediate and controlledrelease metoprolol formulations. British journal of clinical pharmacology. 2015;80(5):102130.

103. Rocha MBS, De Nucci G, Lemos FN, de Albuquerque Lima Babadopulos RF, Rohleder AVP, Fechine FV, et al. Impact of Bariatric Surgery on the Pharmacokinetics Parameters of Amoxicillin. Obes Surg. 2018.

104. Kopp Kallner H, Thunell L, Brynhildsen J, Lindeberg M, Gemzell Danielsson K. Use of Contraception and Attitudes towards Contraceptive Use in Swedish Women--A Nationwide Survey. PLoS One. 2015;10(5):e0125990.

105. Zigler RE, McNicholas C. Unscheduled vaginal bleeding with progestin-only contraceptive use. Am J Obstet Gynecol. 2017;216(5):443-50.

106. Belsey EM. Vaginal bleeding patterns among women using one natural and eight hormonal methods of contraception. Contraception. 1988;38(2):181-206.

107. Broome M, Fotherby K. Clinical experience with the progestogen-only pill. Contraception. 1990;42(5):489-95.

108. Johansson ED, Kral JG. Oral contraceptives after intestinal bypass operations. JAMA. 1976;236(25):2847.

109. Andersen AN, Lebech PE, Sorensen TI, Borggaard B. Sex hormone levels and intestinal absorption of estradiol and D-norgestrel in women following bypass surgery for morbid obesity. Int J Obes. 1982;6(1):91-6.

110. Victor A, Odlind V, Kral JG. Oral contraceptive absorption and sex hormone binding globulins in obese women: effects of jejunoileal bypass. Gastroenterol Clin North Am. 1987;16(3):483-91.

111. Schneider BE, Mun EC. Surgical management of morbid obesity. Diabetes Care. 2005;28(2):475-80.

112. Mechanick JI, Youdim A, Jones DB, Garvey WT, Hurley DL, McMahon MM, et al. Clinical practice guidelines for the perioperative nutritional, metabolic, and nonsurgical support of the bariatric surgery patient--2013 update: cosponsored by American Association of Clinical Endocrinologists, The Obesity Society, and American Society for Metabolic \& Bariatric Surgery. Obesity. 2013;21 Suppl 1:S1-27.

113. RCOG. The role of bariatric surgery in improving reproductive health. Scientific Impact Paper. 2015(No.17).

114. Willis GB. Cognitive interviewing A "How To" Guide. 1999 Meeting of the American Statistical Association1999.

115. Gabrielsson J, Weiner D. Non-compartmental analysis. Methods Mol Biol. 2012;929:377-89.

116. Saeves I, Vethe NT, Bergan S. Quantification of 6 glucocorticoids in human plasma by liquid chromatography tandem mass spectrometry: method development, validation, and assessment of matrix effects. Ther Drug Monit. 2011;33(4):402-10.

117. Spona J, Feichtinger W, Kindermann C, Wunsch C, Brill K. Inhibition of ovulation by an oral contraceptive containing 100 micrograms levonorgestrel in combination with 20 micrograms ethinylestradiol. Contraception. 1996;54(5):299-304. 
118. Endrikat J, Blode H, Gerlinger C, Rosenbaum P, Kuhnz W. A pharmacokinetic study with a low-dose oral contraceptive containing 20 microg ethinylestradiol plus 100 microg levonorgestrel. The European journal of contraception \& reproductive health care : the official journal of the European Society of Contraception. 2002;7(2):79-90.

119. Kothare PA, Seger ME, Northrup J, Mace K, Mitchell MI, Linnebjerg H. Effect of exenatide on the pharmacokinetics of a combination oral contraceptive in healthy women: an open-label, randomised, crossover trial. BMC Clin Pharmacol. 2012;12:8.

120. Messerlian C, Basso O. Cohort studies in the context of obstetric and gynecologic research: a methodologic overview. Acta Obstet Gynecol Scand. 2018;97(4):371-9.

121. Streiner DL NG. Health measurement scales. A practical guide to their development and use. : Oxford University Press 1995.

122. Wennerholm C, Grip B, Johansson A, Nilsson H, Honkasalo ML, Faresjo T.

Cardiovascular disease occurrence in two close but different social environments. Int J Health Geogr. 2011;10:5.

123. Edwards PJ, Roberts I, Clarke MJ, Diguiseppi C, Wentz R, Kwan I, et al. Methods to increase response to postal and electronic questionnaires. Cochrane Database Syst Rev. 2009(3):MR000008.

124. Johnson TP, Wislar JS. Response rates and nonresponse errors in surveys. JAMA. 2012;307(17):1805-6.

125. Brtnikova M, Crane LA, Allison MA, Hurley LP, Beaty BL, Kempe A. A method for achieving high response rates in national surveys of U.S. primary care physicians. PLoS One. 2018;13(8):e0202755.

126. McHugh ML. Interrater reliability: the kappa statistic. Biochem Med (Zagreb). 2012;22(3):276-82.

127. Lindh I, Hognert $\mathrm{H}$, Milsom I. The changing pattern of contraceptive use and pregnancies in four generations of young women. Acta Obstet Gynecol Scand. 2016;95(11):1264-72.

128. Louis TA, Lavori PW, Bailar JC, 3rd, Polansky M. Crossover and self-controlled designs in clinical research. N Engl J Med. 1984;310(1):24-31.

129. Bjornsson TD, Wagner JA, Donahue SR, Harper D, Karim A, Khouri MS, et al. A review and assessment of potential sources of ethnic differences in drug responsiveness. J Clin Pharmacol. 2003;43(9):943-67.

130. Goday Arno A, Farre M, Rodriguez-Morato J, Ramon JM, Perez-Mana C, Papaseit E, et al. Pharmacokinetics in Morbid Obesity: Influence of Two Bariatric Surgery Techniques on Paracetamol and Caffeine Metabolism. Obes Surg. 2017;27(12):3194-201.

131. Kroll D, Nett PC, Borbely YM, Schadelin S, Bertaggia Calderara D, Alberio L, et al. The effect of bariatric surgery on the direct oral anticoagulant rivaroxaban: the extension study. Surgery for obesity and related diseases : official journal of the American Society for Bariatric Surgery. 2018;14(12):1890-6.

132. Clarke LL. A guide to Ussing chamber studies of mouse intestine. American journal of physiology Gastrointestinal and liver physiology. 2009;296(6):G1151-66.

133. Mosher WD, Lantos H, Burke AE. Obesity and contraceptive use among women 2044years of age in the United States: results from the 2011-15 National Survey of Family Growth (NSFG). Contraception. 2018;97(5):392-8.

134. ACOG Practice Bulletin No. 206: Use of Hormonal Contraception in Women With Coexisting Medical Conditions. Obstet Gynecol. 2019;133(2):e128-e50. 
135. Briggs $P$, Serrani M, Vogtlander K, Parke S. Continuation rates, bleeding profile acceptability, and satisfaction of women using an oral contraceptive pill containing estradiol valerate and dienogest versus a progestogen-only pill after switching from an ethinylestradiol-containing pill in a real-life setting: results of the CONTENT study. Int J Womens Health. 2016;8:477-87.

136. Luo L, Luo B, Zheng Y, Zhang H, Li J, Sidell N. Oral and intrauterine progestogens for atypical endometrial hyperplasia. Cochrane Database Syst Rev. 2018;12:CD009458.

137. Mody SK, Hacker MR, Dodge LE, Thornton K, Schneider B, Haider S. Contraceptive counseling for women who undergo bariatric surgery. Journal of women's health. 2011;20(12):1785-8.

138. Mittal P, Dandekar A, Hessler D. Use of a modified reproductive life plan to improve awareness of preconception health in women with chronic disease. Perm J. 2014;18(2):2832. 


\section{Errata}

\section{Paper II}

\begin{tabular}{|l|l|l|}
\hline Page/line & Original text & Correction \\
\hline 2068/ right column/line 10 & $\begin{array}{l}\text { The main sources of this } \\
\text { information were midwives } \\
\text { and gynecologists }\end{array}$ & $\begin{array}{l}\text { The main postoperative } \\
\text { contraceptive counselors and } \\
\text { prescribers were } \\
\text { gynecologist and midwifes. }\end{array}$ \\
\hline $2068 /$ Table 2 column 3 & $1-2$ years after surgery & 12 months after surgery \\
\hline $2069 /$ left column/line 4 & $\begin{array}{l}\text { A majority also stated that } \\
\text { they received no or } \\
\text { insufficient contraceptive } \\
\text { counselling }\end{array}$ & $\begin{array}{l}\text { Almost one fifth stated that } \\
\text { they received no or } \\
\text { insufficient contraceptive } \\
\text { counselling. }\end{array}$ \\
\hline $2069 /$ right column/ line 17 & $\begin{array}{l}\text { there were slightly more } \\
\text { smokers in the non- } \\
\text { responding group }\end{array}$ & $\begin{array}{l}\text { there were significantly } \\
\text { more smokers in the non- } \\
\text { responding group }\end{array}$ \\
\hline & \multicolumn{2}{|l}{} \\
\hline
\end{tabular}




\section{Appendices}

\section{Appendix 1}

\section{Preventivmedel i samband med fetmakirurgi}

Svara på nedanstående frågor så noga du kan. Använd kulspetspenna och markera med ett tydligt kryss i rutan. Om du ändrar dig, fyll då i hela rutan med färg och sätt ett tydligt kryss i den ruta som är den rätta.

Frågeformuläret består av 4 delar. Frågor om din bakgrund, frågor om din operation, frågor om ditt preventivmedelsbruk och till sist frågor om menstruation och graviditet efter operationen.

Vi är intresserade av dina svar även om du inte har några erfarenheter av preventivmedel eller inte använder preventivmedel just idag.

\section{Frågor om din bakgrund}

1. Vilket år är du född?

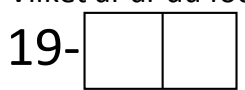

2. Vilken är din högsta helt genomförda utbildning?

$\square$ Grundskola eller motsvarande

Gymnasieutbildning eller motsvarande

Universitets- eller högskoleutbildning

3. Vilket är ditt modersmål?

$\square$ Svenska

$\square$ Annat nordiskt språk

Annat språk

4. Röker du dagligen?

$\square \mathrm{Ja}$

$\mathrm{Nej}$

5. Vilken är din huvudsakliga sysselsättning?

Förvärvsarbetande, hel- eller deltid

Hemarbetande/"hemmafru"

Långtidssjukskriven/sjukpensionär/aktivitetsstöd

Studerar

Arbetssökande

Föräldraledig 
6. Vilket är ditt civilstånd?

$\square$ Gift/sambo

$\square$ Lever ensam utan fast partner/singel

$\square$ Särbo

7. Hur många ggr har du totalt sett varit gravid (räkna med alla födda barn, missfall och aborter)?
$\square 0$
$\square 1$
$\square 2$
3
$\square 4$
$\square 5$
6
mer än 6

8. Hur många barn har du fött? (Vaginalt eller med kejsarsnitt)

$\begin{array}{lll}\square 0 & \square 1 & \square 2\end{array}$

9. Har du opererat bort båda äggstockarna?

$\square \mathrm{Ja}$

$\square \mathrm{Nej}$

$\square$ Vet ej

10. Har du opererat bort livmodern?

$\square \mathrm{Ja}$

$\square \mathrm{Nej}$

$\square$ Vet ej

\section{Frågor om din fetmaoperation}

11. Vilket år blev du opererad?

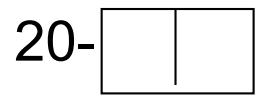

12. Hur lång tid har det gått sedan du opererades?

$\square$ mindre än 6 månader

$\square$ 6-12 månader

$\square$ 1-2 år

$\square$ mer än 2 år

$\square$ vet ej/minns ej 
13. Hur mycket väger du idag?

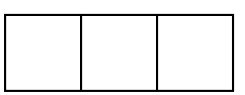

14. Vilken var din vikt innan du opererades? (Räkna inte bort ev ordinerad snabbantning omedelbart före operationen)

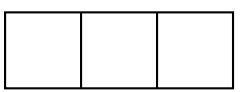

15. Hur lång är du?

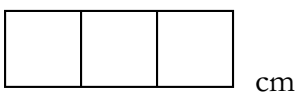

16. Hur ofta har du vanligtvis avföring?

$\begin{array}{cccccccc}\begin{array}{c}\text { Varannan } \\ \text { dag eller }\end{array} & \begin{array}{c}\text { En gång } \\ \text { per dag }\end{array} & \begin{array}{c}2 \text { gånger } \\ \text { per dag }\end{array} & \begin{array}{c}3 \text { gånger } \\ \text { per dag }\end{array} & \begin{array}{c}4 \text { gånger } \\ \text { per dag }\end{array} & \begin{array}{c}5 \text { gånger } \\ \text { per dag }\end{array} & \begin{array}{c}6 \text { gånger } \\ \text { per dag }\end{array} & \begin{array}{c}\text { Fler än } 6 \\ \text { gånger } \\ \text { mer sällan }\end{array} \\ \square & \square & \square & \square & \square & \square & \square & \square\end{array}$

17. Hur är din avföring vanligtvis?
Hård
$\square$ Normal
$\square$ som "gröt"
$\square$ som "välling"
$\square$ vattentunn
$\square$ omväxlande lös och hård

18. Besväras du av kräkningar?

$\begin{array}{cccc}\text { Aldrig 1-2 gånger } & \text { 3-5 gånger } & \begin{array}{c}\text { I stort sett } \\ \text { per vecka }\end{array} \text { fler än en } \\ \text { dagligen } & \begin{array}{c}\text { dag } \\ \text { dag per }\end{array}\end{array}$




\section{Frågor om preventivmedel}

19. Använde du något/några av nedanstående preventivmedel året innan din operation?

Fyll i ett svar för varje uppräknad preventivmedelsmetod

$\begin{array}{lll} & \text { Ja } & \text { Nej } \\ \text { Kopparspiral } & \square & \square \\ \text { Hormonspiral } & \square & \square \\ \text { Cerazette } & \square & \square \\ \text { P-piller } & \square & \square \\ \text { Minipiller } & \square & \square \\ \text { P-spruta } & \square & \square \\ \text { P-stav } & \square & \square \\ \text { P-ring } & \square & \square \\ \text { P-plåster } & \square & \square \\ \text { Kondom/annan metod } & \square & \square \\ \text { Inget } & \square & \\ \text { Vet ej/minns ej } & \square & \end{array}$

Om du är osäker på vilken typ av piller du använt kan du se i bifogad lista

20. Använde du något/några av nedanstående preventivmedel året efter din operation?

Fyll i ett svar för varje uppräknad preventivmedelsmetod

$\begin{array}{lll} & \text { Nej } \\ \text { Kopparspiral } & \square & \square \\ \text { Hormonspiral } & \square & \square \\ \text { P-piller } & \square & \square \\ \text { Minipiller } & \square & \square \\ \text { Cerazette } & \square & \square \\ \text { P-spruta } & \square & \square \\ \text { P-stav } & \square & \square \\ \text { P-ring } & \square & \square \\ \text { P-plåster } & \square & \square \\ \text { Kondom/annan metod } & \square & \square \\ \text { Inget } & \square & \\ \text { Vet ej/minns ej } & \square & \end{array}$

Om du är osäker på vilken typ av piller du använt kan du se i bifogad lista 
21. Använder du något/några av nedanstående preventivmedel idag?

Fyll i ett svar för varje uppräknad preventivmedelsmetod

$\begin{array}{lll} & \text { Ja } & \text { Nej } \\ \text { Kopparspiral } & \square & \square \\ \text { Hormonspiral } & \square & \square \\ \text { P-piller } & \square & \square \\ \text { Minipiller } & \square & \square \\ \text { Cerazette } & \square & \square \\ \text { P-spruta } & \square & \square \\ \text { P-stav } & \square & \square \\ \text { P-ring } & \square & \square \\ \text { P-plåster } & \square & \square \\ \text { Kondom/annan metod } & \square & \square \\ \text { Inget } & \square & \\ \text { Vet ej/minns ej } & \square & \end{array}$

Om du är osäker på vilken typ av piller du använt kan du se i bifogad lista

22. Var du nöjd med det preventivmedel som du använde året innan operationen?

$\mathrm{Ja}$

$\square$ Nej

$\square$ Jag använde inget preventivmedel året innan operationen

$\square$ Vet ej/minns ej

23. Vilka råd om graviditet och preventivmedel fick du i samband med din operation? Svara på samtliga alternativ

$$
\text { Ja Nej Vet ej/minns ej }
$$

Graviditet skall undvikas

efter operationen.

Annat råd om graviditet

Råd om lämpliga preventivmedel

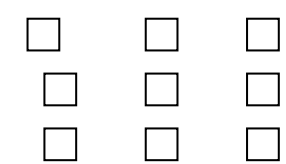

Om du fick rådet att undvika graviditêt, hur lång tid blev du rekommenderad att inte bli gravid efter operationen?

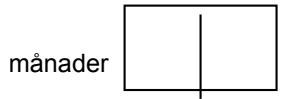


24. Hade du behövt mer information om preventivmedel efter din operation?

$\square \mathrm{Ja}$

$\square \mathrm{Nej}$

Vet ej/minns ej

25. Har du använt något preventivmedel efter din operationen?

$\mathrm{Ja}$

$\mathrm{Nej}$

Vet ej/minns ej

\section{Om du har svarat nej på denna fråga - hoppa till fråga 32 (sid 7)!}

26. Fick du i samband med operationen (innan eller efter) hjälp (ex en remiss) med att få kontakt med gynekolog eller barnmorska för att diskutera preventivmedel?

$\square$ Ja

$\square \mathrm{Nej}$

$\square$ Nej, men jag uppmanades att själv kontakta barnmorska eller gynekolog

$\square$ Vet ej/minns ej

27. Vem rekommenderade dig och förskrev dig ditt preventivmedel efter operationen? Vi ber dig att svara på samtliga alternativ.

$$
\text { Ja Nej Vet ej/minns ej }
$$

Kirurg (i samband med operationen)

Gynekolog

Barnmorska

Annan

Ingen rekommenderade/talade

med mig om preventivmedel

28. Är du nöjd med det preventivmedel du använder idag?

$\mathrm{Ja}$

Nej

Vet ej

Jag har inget preventivmedel

Om du har svarat att du inte har något preventivmedel hoppa till fråga 32 (sid 7)! 
29. Skulle du vilja byta preventivmedel?

$\square \mathrm{Ja}$

$\square \mathrm{Nej}$

Vet ej

30. Har du idag någon/några av de bieffekter/biverkningar av preventivmedel som räknas upp nedan?

\begin{tabular}{|c|c|c|}
\hline & Ja & Nej \\
\hline \multicolumn{3}{|l|}{ Acne } \\
\hline Illamående & L & L \\
\hline Humörpåverkan/nedstämdhet & 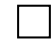 & \\
\hline \multicolumn{3}{|l|}{ Minskad sexlust } \\
\hline \multicolumn{3}{|l|}{ Bröstspänningar } \\
\hline \multicolumn{3}{|l|}{ Oönskade blödningar } \\
\hline \multicolumn{3}{|c|}{ (mellanblödningar/långa menstruationer) } \\
\hline Utebliven menstruation & $\square$ & $\square$ \\
\hline Annan biverkan & 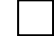 & \\
\hline
\end{tabular}

31. Har du på grund av preventivmedelsbiverkningar efter din operation bytt preventivmedelsmetod?

$\square \mathrm{Nej}$

$\square$ Ja, en gång

$\square$ Ja, två gånger

$\square$ Ja, fler än två gånger

$\square$ Vet ej/minns ej

\section{Frågor om menstruationscykel och graviditet}

32. Har du varit gravid efter din operation?

$\square$ Ja

$\square$ Nej

$\square$ Vet ej

33. Är du gravid eller ammar du idag?

$\square \mathrm{Ja}$

$\square \mathrm{Nej}$ 
34. Hur är din menscykel idag?

$\square$ Vanligtvis regelbunden (= blödning ungefär varje månad)

$\square$ Vanligtvis regelbunden men ofta kan jag besväras av mellanblödningar

$\square$ Vanligtvis oregelbunden mens och blöder ofta tätare än en gång per månad

$\square$ Vanligtvis oregelbunden mens med glesa menstruationer och det kan ibland hoppa över flera månader

$\square$ Jag har ingen mens

$\square$ Jag är gravid eller ammar och har ingen mens

35. Har du efter din operation blivit gravid trots att du använt preventivmedel på föreskrivet sätt?

$\square \mathrm{Ja}$

$\longrightarrow \mathrm{Nej}$

36. Försöker du nu bli gravid?

$\square \mathrm{Ja}$

$\square$ Nej

Vi ser gärna att du kommer med ytterligare synpunkter och kommentarer. Har du något ytterligare du vill tillägga?

Tack för din medverkan!

Kontrollera att du svarat på samtliga frågor som berör dig

Skicka in formuläret i det bifogade svarskuvertet till avdelningen för Obstetrik \& Gynekologi, Hälsouniversitetet, Universitetssjukhuset, 58185 Linköping. 


\section{Appendix 2}

\section{Ultra performance liquid chromatography/tandem mass spectrometry method (UPLC/MS-MS).}

The solid phase extraction method was based on a method previously described by Seaves et al.. ${ }^{19} 300 \mu 1$ of the patient, standard or quality control (QC) sample were transferred into a $2 \mathrm{ml}$ microcentrifuge tube (Costar, Salt Lake City, UT) followed by $300 \mu 1$ precipitation solution (4:1 Methanol (MeOH): $89 \mathrm{~g} / \mathrm{L}$ $\mathrm{ZnSO}_{4}$ ) and $20 \mu \mathrm{l}$ internal standard solution (Etonogestrel-d7). The samples were vortex-mixed and centrifuged at $18200 \mathrm{~g}$ for five minutes. Then, $500 \mu \mathrm{l}$ of the supernatant was transferred to a new tube and $800 \mu 1$ of $4 \%$ phosphoric acid was added and the samples were vortex-mixed. The resulting mixture was transferred to the solid phase extraction (SPE) plate in two aliquots and then washed with $2 \times 200 \mu 125 \% \mathrm{MeOH}$. The samples were then eluted with $50 \mu \mathrm{l}$ 90:10 Acetonitrile: $\mathrm{MeOH}$ and diluted with $25 \mu 1 \mathrm{H}_{2} \mathrm{O} .5 \mu 1$ were injected into the UPLC system. Chromatographic separation was performed on an Acquity IClass UPLC system using an Acquity BEH C18 column $(1.7 \mu \mathrm{m} 2.1$ x $50 \mathrm{~mm})$ equipped with a guard column (Acquity C18 $1.7 \mu \mathrm{m}$ Vanguard) and a filter at $55^{\circ} \mathrm{C}$. The mobile phases consisted of $0.1 \%$ Formic acid in $10 \mathrm{mM}$ Ammonium formiate in water (A) and Methanol (B).

. The analytes were detected using a Xevo TQ-S micro (ESI interface) (Waters, Milford, MA). Data were analysed using the software MassLynx (Waters). The calibration curve was linear and weighted $1 / x$ by plotting the ratio of the analyte peak area/internal standard peak area as a function of the concentration of the calibrators. The linearity of the calibration curve was considered satisfactory if $r^{2}>0.99$. In-house multilevel calibrator and quality control samples were prepared in human plasma (free of analyte). Concentrations of the unknown samples were calculated from the ratio of analyte to internal standard areas. The standard ranged from 0.025 to $5 \mathrm{ng} / \mathrm{ml}$.

The on-line sample preparation method was based on protein precipitation of 50 $\mu 1$ plasma using $100 \mu \mathrm{l}$ of the same precipitation solution that was used for the SPE method (4:1 MeOH:89 g/L ZnSO4). $10 \mu 1$ internal standard solution in $\mathrm{MeOH}$ was added prior to precipitation. The samples were then vortex-mixed and centrifuged. $100 \mu 1$ of the supernatant was transferred to a vial. $50 \mu 1$ of the sample was injected onto a trap column and washed with 90:10 H2O:MeOH for one minute. The mobile phase flow was then reversed and diverted onto an analytical column where chromatographic separation was performed. 


\section{Papers}

The papers associated with this thesis have been removed for copyright reasons. For more details about these see:

http://urn.kb.se/resolve?urn=urn:nbn:se:liu:diva-156643 


\section{FACULTY OF MEDICINE AND HEALTH SCIENCES}

Linköping University Medical Dissertation No. 1677, 2019 Department of Clinical and Experimental Medicine

Linköping University

SE-581 83 Linköping, Sweden

www.liu.se

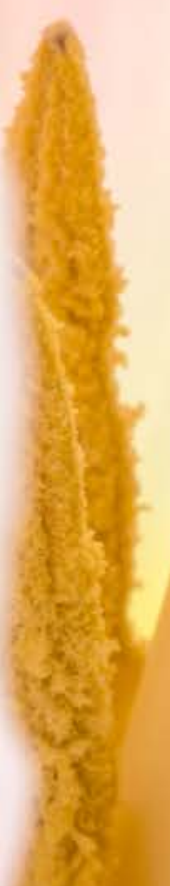

